\title{
RHAMM-Target Peptides as Molecular Imaging Probes for the Imaging of RHAMM-Expressing Cancer Cells
}

\author{
Natalia P. Akentieva $^{1, *(\mathbb{D})}$, Alexey F. Topunov ${ }^{2(\mathbb{D})}$ \\ 1 Laboratory Biochemical and Cellular Studies, Department Kinetics of Chemical and Biological Processes, Institute of \\ Problems of Chemical Physics, Russian Academy of Sciences, 142432 Moscow Region, Academician Semenov Avenue \\ 1, City Chernogolovka, Russia; na_aken@icp.ac.ru (N.P.A.); \\ 2 Bach Institute of Biochemistry, Federal Research Center of Biotechnology, Russian Academy of Sciences, Leninsky \\ prospect 33, Moscow 119071, Russia; aftopunov@yandex.ru (A.F.T.); \\ * Correspondence: na_aken@icp.ac.ru;
}

Scopus Author ID 56370037400

Received: 11.03.2021; Revised: 5.04.2021; Accepted: 8.04.2021; Published: 19.04.2021

\begin{abstract}
The incidence of cancer in the world is growing steadily. Therefore, it is necessary to develop new approaches for the early diagnosis of cancer. This work is devoted to the study of the potential of RHAMM-target peptides for molecular diagnosis of cancer. The key amino acids of the RHAMM target peptides were identified by the alanine scan method. The specificity of binding of peptides to RHAMMCT was assessed using competitive HA substitution by the ELISA method. RHAMM-CT was obtained by genetic engineering and isolated by affinity chromatography. The interaction of RHAMM target peptides with the surface receptor of tumor cells was evaluated by confocal microscopy. It has been shown that fragment EEGEEZ in the peptides' composition is necessary for binding to the RHAMMCT. The results showed that the RHAMM-target peptides bind specifically to the RHAMM-CT and competitively substituted HA at the RHAMM. It has been found that aggrecan is unable to displace peptides from the HA binding site of RHAMM-CT. The results showed that the FITC peptide binds specifically to RHAMM on the surface of prostate cancer cells. Therefore, RHAMM-target peptides have the potential for early molecular diagnosis of cancer.
\end{abstract}

Keywords: RHAMM-target peptides; RHAMM/HMMR; imaging probes; cancer

(C) 2021 by the authors. This article is an open-access article distributed under the terms and conditions of the Creative Commons Attribution (CC BY) license (https://creativecommons.org/licenses/by/4.0/).

\section{Introduction}

Currently, oncological diseases are in second place after cardiovascular diseases. The incidence and mortality of cancer are steadily increasing. According to statistics, more than 11 million people fall ill with cancer every year [1]. Only early diagnosis of cancer can improve the survival rate of cancer patients.

Although significant progress has been made in cancer treatment in recent years, most modern cancer treatments include surgery or chemotherapy, radiation, and hormonal therapy, which have changed little over the past decade and have several limitations. So surgical intervention and radiotherapy are often used already at the last stages of cancer development. These methods are not specific; they do not suppress the formation of metastases. Chemotherapy methods also have several disadvantages. Currently used chemotherapy drugs are based on the rapid division of tumor cells and do not consider other specific properties of cancer cells $[2,3]$. In addition, many anticancer drugs are highly toxic, exhibit side effects, have poor solubility, poor permeability into the cell, and poor biocompatibility [4]. Therefore, 
at present, new peptide-based anticancer drugs have appeared. Peptides are low molecular weight compounds and can be engineered from endogenous proteins. It should be noted that peptides are easily modified, their synthesis is simple, cheap, and cost-effective.

Peptides are used to diagnose and treat cancer, providing specificity for tumor tissues, reducing the likelihood of developing drug resistance, and low toxicity [5].

Each tumor has its own specific features (sometimes specific to the patient, the socalled molecular signatures), which are expressed in the tumor in large quantities and/or located in a different place than normal tissue [6]. This tumor-specific signature enables the development of targeted agents for the early detection, diagnosis, and treatment of cancer. Synthetic polypeptides are excellent candidates for cancer diagnostics. In particular, peptide ligands are advantageous due to their small size, easy and affordable production, high specificity, and remarkable flexibility in terms of their sequence and conjugation capabilities [7]. When combined with imaging agents, chemotherapeutic drugs/or nanocarriers, they have proven themselves well for targeted delivery, providing better tumor contouring during imaging and increasing chemotherapy's effectiveness by reducing side effects. In modern personal medicine, the treatment of patients is focused on using specific molecular and genetic characteristics of the tumor and the physiology of a particular patient to select a specific targeted therapy for each patient $[8,9]$. Currently, innovative developments of targeted drugs have appeared in biomedicine, with the help of delivering anticancer drugs to cancer cells.

Targeted peptides have several advantages. In particular, they are not immunogenic, are rapidly cleared from the blood, diffuse better into the tumor due to their lower molecular weight, and are extremely well tolerated by patients [10]. In addition, peptides are generally easy and relatively inexpensive to synthesize and have many possibilities for conjugation with imaging agents, drugs, and nanoparticles for targeted delivery. Thus, peptides provide additional promising therapies for modern personalized/ targeted medicine.

The main component of the extracellular matrix is hyaluronic acid [11]. Hyaluronic acid (hyaluronate, hyaluronan) is a non-sulfonated glycosaminoglycan, which is a part of connective, epithelial, and nervous tissues and is found in many biological fluids (saliva, synovial fluid, etc.) $[12,13]$. Increased HA content is observed in various types of tumors, including carcinomas of breast, prostate, lung, bladder, and ovarian cancer [14-16]. In a number of scientific works, it was found that HA is able to bind with high affinity to the cell surface selectively, and it was shown that HA stimulates cell motility and is responsible for their migration $[17,18]$. Various studies have shown that HA plays a key role in many cellular processes, such as cell proliferation, the development of angiogenesis and invasiveness of tumor cells, in the processes of inflammation and wound healing, as well as in the appearance and development of malignant neoplasms [19, 20]. It is known that

HA is a physiological ligand for the RHAMM receptor (also known as CD168 or HMMR, hyaluronan-mediated motility receptor), as well as a signaling molecule of this receptor that transmits pro-cancer signals into the cell $[22,23]$. Signals from low molecular weight HA through RHAMM enter the cell and contribute to the development and progression of malignant neoplasms.

Low molecular weight HA fragments $(<100 \mathrm{kDa})$ are generated by reactive oxygen or nitrogen species, as well as by hyaluronidases during tissue stress, repair, or cancer, and they have pro-inflammatory and pro-tumor properties [24, 25]. It has been shown that low molecular weight HA accelerates the proliferation and invasiveness of malignant pleural mesothelioma and melanoma cells, and it can be a biomarker for the early diagnosis of these diseases [26, 
27]. Low molecular weight HA fragments activate signaling pathways that send several procancer signals that promote cell proliferation, invasion, adhesion, motility, epithelialmesenchymal transition, and stem cell renewal [28, 29]. Some studies have shown that in tumor cells of the mammary and prostate gland, lungs, urinary bladder, ovaries, elevated levels of HA and RHAMM are observed, which, together with HYAL-1 hyaluronidase, promote tumor growth and are associated with a poor prognostic factor [30, 31]. RHAMM/HMMR (hyaluronmediated mobility receptor, Homo sapiens) is a 725 amino acid (M.w. $95 \mathrm{kDa}$ ) protein [32]. Thus, the interaction of HA with the RHAMM receptor and its role in developing and progressing malignant neoplasms, HA targeting is a promising therapeutic approach to the treatment of cancer [33]. There are many potential points of the HA metabolic pathway that could be targeted, including HA synthesis, overexpression, formation of low molecular weight HA, or interaction of HA with receptors. One such approach is the development of HA-binding peptides that can specifically block HA-stimulated signaling. RHAMM plays a key role in inflammatory and oncological diseases. RHAMM has been shown to be involved in diabetes, arthritis, and many types of cancer, including solid tumors and leukemias [34, 35]. The RHAMM receptor is overexpressed in various cancers, including ovarian, breast, prostate, and pancreatic cancers, renal, bladder, multiple myeloma, leukemia, lymphoma, and colon cancers [36-38]. Therefore, peptides have been developed that mimic either RHAMM itself or HA and have been shown to affect wound healing, inflammatory and tumor processes. Several studies have been carried out to develop peptides, HA mimetics that bind to RHAMM. Several studies have used random phage libraries and rational designs to identify peptides that bind to RHAMM and block RHAMM interactions with HA, as new approaches to specifically replace this protein's HA-binding properties $[39,40]$.

This study aims to identify amino acids in RHAMM-target peptides that are necessary for peptides binding to an RHAMM receptor. Based on the data obtained, synthesize truncated versions of peptides. Investigate the specificity of peptides binding to the RHAMM receptor and the ability to compete with hyaluron at the RHAMM receptor and investigate the specificity of peptide binding to the surface RHAMM receptor of prostate cancer cells.

\section{Materials and Methods}

\subsection{Cell lines and cell culture.}

The following cancer cells were used in work: human prostate cancer cell line (PC3mLN4) and ovarian cancer cell line (SKVO3). The cell line was obtained from the American Type Culture Collection (Manassas, Virginia, Merck, USA). All these tumor cells are characterized by increased expression of RHAMM (Oncomine Research, https://www.oncomine.org/resource/login.html). All cell lines were obtained from the human body. Cells were grown in DMEM growth medium in the presence of $10 \%$ (v / v) FBS and 10 $\mathrm{mM}$ HEPES at $\mathrm{pH}$ 7.2. All cell cultures were grown in a $5 \% \mathrm{CO}_{2}$ incubator at $37^{\circ} \mathrm{C}$ and in a humid atmosphere.

\subsection{Peptide synthesis.}

RHAMM-target peptides (EEDFGEEAEEEA, VEGEGEEEGEEY, FTEAESNMNDLV, GEGEEGEE, DFGEEAEE, RYQLHPYR) were obtained as previously described [41, 42]. 


\subsection{Alanine scan.}

The alanine scan method is the substitution of each amino acid residue with alanine (Ala) in the peptide's sequence sequentially [43]. Peptides were synthesized with a linker (Ahxaminohexanoic acid) and a fluorescein label attached to the N-terminus. For the peptides' alanine screen, EEDFGEEAEEEA has synthesized the next peptides: FITC-AhxAEDFGEEAEEEA-NH $\mathrm{N}_{2}$ FITC-Ahx-EADFGEEAEEEA-NH FITC-AhxEEAFGEEAEEEA-NH $\mathrm{N}_{2}$ FITC-Ahx-EEDAGEEAEEEA-NH2, EEDFAEEAEEEA-NH FITC-Ahx-EEDFGAEAEEEA-NH , FITC-AhxEEDFGEAAEEEA-NH FITC-Ahx-EEDFGEEAAEEA-NH $\mathrm{N}_{2}$ FITC-AhxEEDFGEEAEAEA-NH2, FITC-Ahx-EEDFGEEAEEAA-NH2.

FITC-Ahx-

For alanine screen of peptide, FTEAESNMNDLV has synthesized the next peptides: FITC-Ahx-FTEAESNMNDAV-NH 2 , FITC-Ahx- FTEAESNMNALV-NH, FITC-AhxFTEAESNMADLV-NH $2, \quad$ FITC-Ahx- $\quad$ FTEAESNANDLV-NH,$\quad$ FITC-AhxFTEAESAMNDLV-NH $2, \quad$ FITC-Ahx- $\quad$ FTEAEANMNDLV-NH $\mathrm{N}_{2}, \quad$ FITC-AhxFTEAASNMNDLV-NH $2, \quad$ FITC-Ahx- FTEAESNMNDLV-NH $2, \quad$ FITC-AhxFTAAESNMNDLV-NH FITC-Ahx-FAEAESNMNDLV-NH, FITC-AhxATEAESNMNDLV-NH .

For alanine screen of peptide VEGEGEEEGEEY were synthesized the next peptides: FITC-Ahx-AEGEGEEEGEEY-NH 2 ， FITC-Ahx-VAGEGEEEGEEY- $\mathrm{NH}_{2}$, FITC-AhxVEAEGEEEGEEY - $\mathrm{NH}_{2}, \quad$ FITC-Ahx-VEGAGEEEGEEY- $\quad \mathrm{NH}_{2}, \quad$ FITC-AhxVEGEAEEEGEEY- $\quad \mathrm{NH}_{2}, \quad$ FITC-Ahx-VEGEGAEEGEEY- $\quad \mathrm{NH}_{2}, \quad$ FITC-AhxVEGEGEAEGEEY- $\quad \mathrm{NH}_{2}, \quad$ FITC-Ahx-VEGEGEEAGEEY- $\quad \mathrm{NH}_{2}, \quad$ FITC-AhxVEGEGEEEAEEY- $\quad \mathrm{NH}_{2}, \quad$ FITC-Ahx-VEGEGEEEGAEY- $\quad \mathrm{NH}_{2}, \quad$ FITC-AhxVEGEGEEEGEAY - NH 2 , FITC-Ahx-VEGEGEEEGEEA- $\mathrm{NH}_{2}$.

The purity of peptides was evaluated by ESI-mass-spectrometry ( $>90 \%)$.

Then it was measured the binding of each alanine-modified FITC-peptide with recombinant RHAMM-CT protein by ELISA. Briefly, recombinant RHAMM-CT (100 $\mu 1,100$ $\mu \mathrm{g} / \mathrm{ml}$ in $0.05 \mathrm{M}$ PBS, $\mathrm{pH} 7.6)$ immobilized on a 96-well plate and incubated at $4{ }^{\circ} \mathrm{C}$ for 24 hours. Then the plate was washed three times with PBS-Tween-20 buffer $(0.05 \%, 200 \mu 1 /$ well), and blocking buffer (5\% Tween-20 in PBS, $200 \mu \mathrm{l} /$ well) was added, the plate was incubated for 1 hour at RT. The plate was then washed three times again with buffer as described above. After that, alanine-modified FITC-peptides were added to the wells (final concentration of peptides $100 \mu \mathrm{g} / \mathrm{ml}$ ), and the plate was incubated for 24 hours at $4^{\circ} \mathrm{C}$. The plate was then washed as described above, and the fluorescence intensity was measured at $485 / 535 \mathrm{~nm}$. A negative control (no immobilized RHAMM-CT) that showed minimal background fluorescence was subtracted for each measurement.

\subsection{RHAMM-CT protein purification.}

Recombinant protein RHAMM-CT (aa. 706-766, sequence: RDSYAQLLGH QNLKQKIKHV VKLKDENSQL KSEVSKLRSQ LVKRKQNELR LQGELDKALGI, M.W. $7.1 \mathrm{kDa}, \mathrm{pI}=10.1$ ) was isolated from $E$. coli BL21 (D3) strain carrying the recombinant plasmid pPAL7-RHAMM. Bacteria were grown overnight in LB medium at $37^{\circ} \mathrm{C}$ containing ampicillin $(100 \mu \mathrm{g} / \mathrm{ml})$ and $0.5 \%$ glucose; cells were grown to the middle of the logarithmic phase, first in the absence of the lac promoter inductor isopropylthio- $\beta$-D-galactopyranoside (IPTG). Upon reaching turbidity of the medium OD600 of 0.4-0.6, IPTG was added to a 
concentration of $2 \mathrm{mM}$, and the expression of the recombinant RHAMM was continued under the control of the induced lac promoter for 4 hours at $37^{\circ} \mathrm{C}$. Then bacterial cells were pelleted by centrifugation at $10,000 \mathrm{~g}$ for $20 \mathrm{~min}$. After that, bacterial cells were resuspended in lysis buffer $(0.2 \mathrm{M}$ sodium phosphate, $0.2 \mathrm{M}$ potassium acetate, $1 \%$ Triton $\mathrm{X}-100$ and $0.1 \%$ protease inhibitors, $\mathrm{pH} 7.0)$, treated with ultrasound (60 s, $10 \mathrm{~s} /$ pulse), and centrifuged at $12000 \mathrm{~g}, 4^{0} \mathrm{C}$ for $20 \mathrm{~min}$. The resulting supernatant was transferred to a clean tube and filtered (using a 0.45 $\mu \mathrm{m}$ filter). According to the manufacturer's protocol, the recombinant RHAMM-CT bound to eXact was purified using an affinity sorbent (Profinity eXact, Bio-Rad, USA) according to the manufacturer's protocol [44]. For this, the resulting lysate was applied to a gravity column packed with an affinity sorbent (4 ml of Profinity eXact sorbent, column $15 \times 1.5 \mathrm{~cm}$ ) and equilibrated with a washing buffer ( $0.2 \mathrm{M}$ sodium phosphate, $\mathrm{pH}$ 7.0). The column was washed with decontamination buffer, and the recombinant RHAMM-CT was eluted with elution buffer (0.2 M sodium phosphate, $0.1 \mathrm{M}$ sodium fluoride, $\mathrm{pH}$ 7.0). The protein was then dialyzed and concentrated using a filter (EMD Millipore, Temecula, CA, USA) in a buffer consisting of 0.2 $\mathrm{M}$ sodium phosphate and 0.2 M potassium acetate ( $\mathrm{pH}$ 7.0).

\subsection{Protein detection.}

Protein has been measured by Quickstart Bradford protein assay using standard procedure [45].

\subsection{SDS-polyacrylamide gel electrophoresis.}

The purity of the resulting recombinant RHAMM-CT protein was determined by $10 \%$ one-dimensional SDS-PAGE electrophoresis, according to the protocol described in the article [46]. An aliquot of protein solution $(0.01 \mathrm{ml}, 6 \mu \mathrm{g}$ protein, and $0.005 \mathrm{ml}, 3 \mu \mathrm{g}$ protein) was added to $0.01 \mathrm{ml}$ SDS buffer. SDS buffer contained $130 \mathrm{mM}$ Tris (pH 6.8), 4.2\% (w / v) SDS, $20 \%$ (v/ v) glycerol, $0.003 \%$ (wt / vol) bromophenol blue, and 10\% (v/v) 2 -mercaptoethanol (fresh added). The tubes with the samples were incubated at $30^{\circ} \mathrm{C}$ for $1 \mathrm{~min}$ and then boiled for 1 min. Thereafter, the samples were loaded onto a 10\% SDS-polyacrylamide gel, and electrophoresis was performed.

\subsection{Western blot analysis.}

RHAMM-CT was identified using anti-RHAMM antibodies by Western blot analysis. Western blotting was performed according to the protocol described in the article [47]. Briefly: RHAMM-CT protein was used for Western blotting. SDS buffer (0.5 M Tris, $\mathrm{pH} 6.8,50 \%$ glycerol, $10 \%$ SDS, $\beta$-mercaptoethanol, bromophenol blue) was added to the RHAMM-CT protein $(0.005 \mathrm{ml}, 3 \mu \mathrm{g})$, the sample was heated for 5 minutes at $95^{\circ} \mathrm{C}$. The sample was then centrifuged, loaded onto a 10\% Bis-Tris denaturing gel, and 10\% SDS-PAGE was performed. The separated proteins were transferred onto an Amersham Hypond-P-PVDF membrane (Sigma-Aldrich, USA). Blotting was performed for 1-2 hours, voltage 45, current $350 \mathrm{~mA}$. Nonspecific binding sites were blocked by immersing the membrane in Tris buffer (TBS-T: TBS / 0.1\% Tween-20, 5\% skimmed milk powder) and incubated for 1 hour at RT on an orbital shaker. Next, the membrane was washed twice with wash buffer (TBS / 0.1\% Tween-20). Then the membrane was incubated with primary antibodies. Antibodies were used in work: primary monoclonal mouse anti-RHAMM 6B7D8 ab (Santa Cruz, CA, USA), secondary mouse antibodies conjugated with horseradish peroxidase (Santa Cruz, CA, USA). Primary antibodies 
were diluted 1: 1000 in TBS-T solution and the membrane was incubated in diluted primary antibodies for 1 hour at room temperature on an orbital shaker. Thereafter, the membrane was rinsed twice with washing buffer and then washed again in $50 \mathrm{ml}$ of washing buffer for $15 \mathrm{~min}$ at RT. Thereafter, the membrane was again washed three times for 5 min with washing buffer at RT. After washing, the membrane was incubated with secondary antibodies conjugated with horseradish peroxidase, diluted in a ratio of 1: 10,000 in TBS-T solution for 1 hour at RT on an orbital shaker. Then the membrane was rinsed twice with washing buffer and washed in 50 $\mathrm{ml}$ of washing buffer for $15 \mathrm{~min}$ at RT. Thereafter, the membrane was washed three times for 5 min with fresh changes of wash buffer at room temperature. Then the membrane was dried, secondary antibodies conjugated with horseradish peroxidase were detected using Enhanced chemiluminescence plus (Perkin Elmer Life science, Boston, MA, USA) and photographed using the Ultra-Lum imaging system (Ultra-Lum Inc., Claremont, CA, USA).

\subsection{Assay of binding of FITC peptides to RHAMM-CT.}

The ability of FITC peptides (EEDFGEEAEEEA, FTEAESNMNDLV, GEGEEGEE, DFGEEAEE, RYQLHPYR) to bind to recombinant RHAMM-CT was investigated. Recombinant RHAMM-CT $(100 \mu \mathrm{l}, 10 \mu \mathrm{g} / \mathrm{ml}$ in $0.05 \mathrm{M}$ PBS, pH 7.6) was immobilized on a 96-well plate (final protein concentration $1 \mu$ /well) and incubated at $4^{\circ} \mathrm{C}$ for 24 hours. Then the plate was washed three times with PBS-Tween-20 buffer $(0.05 \%, 200 \mu \mathrm{l} /$ well), and blocking buffer (5\% Tween-20 in PBS, $200 \mu \mathrm{l}$ / well) was added, the plate was incubated for 1 hour at RT. The plate was then rewashed three times with buffer as described above. After that, FITC-peptides were added to the wells (final concentration of peptides $40 \mu \mathrm{M}$ ), and the plate was incubated for 24 hours at $4^{\circ} \mathrm{C}$. The plate was then washed as described above, and the fluorescence intensity was measured at $485 / 535 \mathrm{~nm}$. A negative control (no immobilized RHAMM-CT) that showed minimal background fluorescence was subtracted for each measurement.

\subsection{HA labeling with a fluorescent dye (Cy5.5).}

HA labeling with a fluorescent dye (Cy5.5) was performed according to the protocol described in the article [48]. Briefly: NHS-Cy5.5 activated ester $(1 \mathrm{mg})$ was dissolved in $1 \mathrm{ml}$ of DMF. Then, $200 \mu \mathrm{g}$ of EDTA and $1 \mathrm{mg}$ of HA (M. w. $220 \mathrm{kDa}$ ) were added to $0.2 \mathrm{ml}$ of NHS-Cy5.5 solution and brought to a final volume of $2 \mathrm{ml}$ with $0.1 \mathrm{M}$ phosphate buffer $(\mathrm{pH}$ 8.3). The resulting solution was mixed well on a vortex. The solution was then incubated at RT for 4 hours. The HA-Cy5.5 conjugate was purified by gel filtration on Sephadex G-25.

2.10. Analysis of competitive replacement of HA-Cy5.5 with unlabeled peptides on the RHAMM-CT HA-binding site.

To investigate the ability of unlabeled peptides (EEDFGEEAEEEA, GEGEEGEE, RYQLHPYR) to compete with HA for the binding site on RHAMM-CT, we used HA-Cy5.5 $(100 \mu \mathrm{l}, 10 \mu \mathrm{g} / \mathrm{ml}$ in $0.05 \mathrm{M}$ PBS, pH 9). RHAMM-CT was immobilized on a 96-well plate (final amount of protein $1 \mu \mathrm{g} /$ well) and incubated for 24 hours at $4^{0} \mathrm{C}$. The plate was washed three times with PBS-Tween-20 buffer $(0.05 \%, 200 \mu \mathrm{l} /$ well), then blocking buffer (5\% Tween20 in PBS, $200 \mu \mathrm{l} /$ well) was added and incubated for 1 hour at RT. Thereafter, the plate was washed three times with buffer as described above. Then peptides $(10 \mu \mathrm{g} / \mathrm{ml})$ and HA- Cy5.5 (M.w. $220 \mathrm{kDa}, 100 \mu \mathrm{l} / \mathrm{well}, 10 \mu \mathrm{g} / \mathrm{ml}$ in PBS) were added to the wells, the plate was incubated 
for 24 hours at $4^{0} \mathrm{C}$. One day later, the plate was washed as described above, and the fluorescence was measured at $650 \mathrm{~nm}$. Unlabeled HA and anti-RHAMM antibodies were used as a positive control.

\subsection{Analysis of competitive substitution of FITC peptides for glycosaminoglycans at the} RHAMM-CT HA-binding site.

The ability of FITC peptides (EEDFGEEAEEEA, GEGEEGEE, RYQLHPYR) to compete with glycosaminoglycan aggrecan for the HA-binding site on RHAMM-CT was investigated. Recombinant RHAMM-CT (100 $\mu \mathrm{l}, 10 \mu \mathrm{g} / \mathrm{ml}$ in $0.05 \mathrm{M}$ PBS, pH 7.6) was immobilized on a 96-well plate (final protein concentration $1 \mu \mathrm{g} / \mathrm{well}$ ) and incubated at $4^{0} \mathrm{C}$ for 24 hours. Then the plate was washed three times with PBS-Tween-20 buffer $(0.05 \%, 200 \mu \mathrm{l} /$ well), and blocking buffer (5\% Tween-20 in PBS, $200 \mu \mathrm{l} /$ well) was added, the plate was incubated for 1 hour at RT. The plate was then rewashed three times with buffer as described above. After that, FITC peptides (final concentration $1 \mu \mathrm{g} / \mathrm{ml}$ ) and aggrecan were added to the wells $(10 \mu \mathrm{g} / \mathrm{ml})$. For positive control, wells were used to which HA was added (M.w. 220 $\mathrm{kDa}, 10 \mu \mathrm{g} / \mathrm{ml}$ ), and the plate was incubated for 24 hours at $4^{0} \mathrm{C}$. The plate was then washed as described above, and the fluorescence intensity was measured at $485 / 535 \mathrm{~nm}$.

\subsection{Analysis of peptide binding by tumor cells.}

Cells (line PC3M-LN4) were cultured in DMEM + 10\% FBS to 90\% density. Cells were detached from the surface with trypsin $(0.25 \%$, Stem Cell Technologies, Corning, USA) and seeded on coverslips (12 x $12 \mathrm{~mm}$, precoated with fibronectin, $50 \mu \mathrm{g} / \mathrm{ml}$ ), placed in 24well culture plates (density 20,000 cells / well). The "starvation" stage was carried out with DMEM $+0.1 \%$ FBS overnight at $37^{\circ} \mathrm{C}$. Thereafter, cells were stimulated with DMEM $+10 \%$ FBS and incubated overnight at $37^{\circ} \mathrm{C}$. Then the culture medium was removed, and the cells were washed with DMEM + 0.1\% FBS. Thereafter, $3 \%$ BSA in DMEM + 0.1\% FBS was added to the cells to block nonspecific binding and incubated for 1 hour at RT. Then, antibodies were added to the cells (1: 100 dilution, mouse IgG Ab, goat anti-RHAMM mAb, or mouse anti$\mathrm{CD} 44 \mathrm{mAb}$ in DMEM $+0.1 \% \mathrm{FBS}$ ) and incubated at $37^{\circ} \mathrm{C}$ for 1 hour. After 1 hour, the culture medium was removed, and the cells were washed with DMEM $+0.1 \%$ FBS at RT. Then FITCpeptides ( $10 \mu \mathrm{g} / \mathrm{ml}$, VEGEGEEEGEEY, EEDFGEEAEEEA, FTEAESNMNDLV) were added to the cells and incubated at $37^{\circ} \mathrm{C}$ for $30 \mathrm{~min}$. The cells were then washed with DMEM $+0.1 \%$ FBS, then with PBS ( $\mathrm{pH}$ 7.6). The coverslips were removed from the wells, and Fluoro-gel 11 containing DAPI (Electron Microscopy Sciences, USA) was added to the cell surface. Then the coverslips were placed on the slides (cells down), and the resulting slides were stored in the dark at $4^{0} \mathrm{C}$. Slides were analyzed on an Olympus FluoView FV1000 confocal microscope (Olympus Corporation, Tokyo, Japan). Cells were photographed using Olympus FluoView FV1000 software (FV10-ASW version 01.07: Olympus) connected to an inverted microscope system (IX81). TIFF images were analyzed using Image J software (NIH, USA). Each image was converted to 8-bit format and analyzed in the range of threshold values of 20 and 255. Using the ImageJ software, images (ROI, Region of Interest) of the analyzed cells were selected. The average fluorescence value of each ROI was obtained using 8-bit images and presented as a histogram. The results were analyzed by statistical analysis using One-Way ANOVA. Differences were considered statistically significant at $\left(*_{-} \mathrm{p}<0.05\right)$. An asterisk 
indicates statistically significant differences between cells treated with antibodies against RHAMM and all other treatments.

\subsection{Statistical analysis.}

Statistical analysis was performed using Prism 4 software (GraphPad Software, Inc.) to assess statistically significant differences. All experiments were performed three times. For comparative analysis of the results, one-way analysis of variance (ANOVA) was used, where $* \mathrm{p}<0.05$ was considered significant.

\section{Results and Discussion}

\subsection{Preparation and purification of recombinant RHAMM-CT protein.}

To identify peptides with high affinity for the RHAMM HA-binding domain, we used various assay methods, such as ELISA analysis of peptide binding to a recombinant RHAMM protein and in vitro analysis of peptide binding to the surface of tumor cells. For this purpose, a recombinant RHAMM-CT protein was obtained. The content of the RHAMM protein in biological material is extremely low, therefore, the development of preparative methods for obtaining the native RHAMM protein is impractical. In this regard, we obtained the RHAMM protein using genetic engineering methods. The RHAMM protein contains an HA-binding domain, which is located near the carboxyl terminus (CT) and is composed of basic amino acids such as lysine (Lys), arginine (Arg), or leucine (Leu). The RHAMM-CT HA-binding domain is the main "Leu-zipper" domain, which consists of basic amino acid residues and does not contain acidic residues $\left({ }^{718}\right.$ LKQKIKHVVKLKDENSQL KSEVSKLRSQ LVKRK $\left.{ }^{750}\right)$. It has been established that the interaction of HA with RHAMM is based on ionic contacts between positively charged residues in the protein and negatively charged carboxyl groups on HA, as well as on hydrophobic interactions between lipophilic regions of the RHAMM protein [49-51].

To analyze peptide binding specificity, we isolated the recombinant protein RHAMMCT (aa. 706-767, M.w. 7, $2 \mathrm{kDa}, \mathrm{pI}=10.1$ ) from $E$. coli carrying the recombinant plasmid pPAL7-RHAMM-CT. For this, the E. coli BL21 (DE3) strain was chosen as an expression system. The Mus. musculus (house mice) gene library was used as the source of the RHAMMCT gene. A fragment of the RHAMM gene corresponding to the RHAMM-CT coding sequence $\quad\left({ }^{706}\right.$ RDSYAQLLGH QNLKQKIKHVVKLKDENSQL KSEVSKLRSQ LVKRKQNELR LQGELDKLQI ${ }^{767}$ ) and bearing the HA-binding domain was isolated by amplification. Then RHAMM-CT was cloned into the pPAL7 vector and expressed in the $E$. coli strain BL21 (DE3). This E. coli BL21 (DE3) strain provided a high and stable level of expression of the target protein. Expression of the RHAMM-CT gene was carried out in the $E$. coli strain transfected with the recombinant plasmid pPAL7, in the culture medium, first in the absence of the inducer of the lac promoter isopropylthio- $\beta$-D-galactopyranoside (IPTG). Upon reaching turbidity of the medium OD 600 of 0.4-0.6, IPTG was added to a concentration of 2 $\mathrm{mM}$, and expression was continued under the induced lac promoter's control. Lysates were obtained from bacterial cells in accordance with the protocol described in Methods, and then the recombinant RHAMM-CT protein was purified by affinity chromatography using a FusionTag Profinity eXact TM purification system (BioRad, USA). This purification system uses an immobilized, specially engineered subtilisin protease that recognizes and specifically binds $(\mathrm{KD}<100 \mathrm{pM})$ to a small $\mathrm{N}$-terminal co-expressed affinity tag (tag-EEDKLFKAL) in the 
fusion-RHAMM-CT protein. Mutant subtilisin protease S189, a functional ligand immobilized on a matrix, was specially developed for affinity chromatography [44, 52]. The S189 subtilisin protease is extremely stable and can be effectively reduced in vitro. A lysate prepared from $E$. coli BL21 (DE3) was loaded onto a column packed with Superflow TM agarose. The subtilisin protease recognized and binding the affinity-labeled tag-RHAMM-CT protein from the protein mixture in the lysate. The column was then washed with buffer to remove nonspecifically unbound proteins. Thereafter, a fluoride buffer (100 mM potassium fluoride) was passed through the column for elution. Potassium fluoride-induced a subtilisin protease that rapidly and specifically cleaved a nine amino acid sequence (EEDKLFKAL) from the RHAMM-CT protein. Thus, the subtilisin protease specifically cleaved and removed the label from the fusion-RHAMM-CT protein directly on the column, resulting in the release of a highly purified recombinant RHAMM-CT protein with a native amino acid sequence.

RHAMM-CT production level in the E. coli strain transfected with the pPAL7 vector was about $50 \mathrm{mg} / \mathrm{L}$ culture. Figure 1 shows the data of the analysis of the recombinant protein RHAMM-CT (a. 706-767, molecular weight 7, $2 \mathrm{kDa}, \mathrm{pI}=10.1$ ) purified from E. coli. The purity of the isolated protein was checked by one-dimensional electrophoresis (10\% SDSPAGE). As can be seen from the presented data, RHAMM-CT is an almost homogeneous protein (purity over $90 \%$ ) with an M. w. of $\sim 7.2 \mathrm{kDa}$, corresponding to the mass of RHAMMCT (Figure 1A). RHAMM identification was performed using monoclonal anti-RHAMM antibodies by Western blot analysis (Figure 1B).

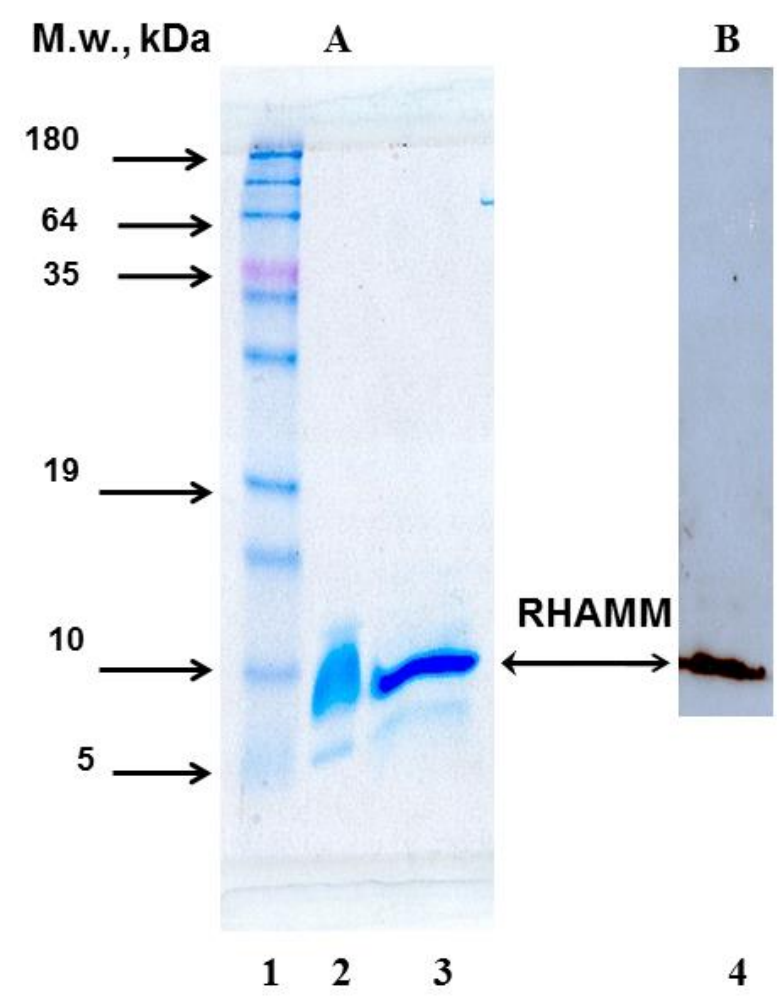

Figure 1. Analysis of the recombinant protein RHAMM-CT by 10\% SDS-PAGE electrophoresis (A) and Western blot analysis (B). 1 - molecular weight standards; 2 - RHAMM-CT (6 $\mu \mathrm{g}) ; 3$ - RHAMM-CT (3 $\mu \mathrm{g}) ; 4$ identification of RHAMM-CT ( $3 \mu \mathrm{g})$ with anti-RHAMM antibodies.

\subsection{Analysis binding of alanine-modified peptides to RHAMM-CT.}

To determine amino acid residues, which are critical for peptide- RHAMM receptor interaction, we performed an alanine scan of peptides EEDFGEEAEEEA, 
FTEAESNMNDLV, and VEGEGEEEGEEY. Table 1 shows the sequence of the eleven synthesized alanine-modified peptides EEDFGEEAEEEA and their calculated and observed masses.

Table 1. Mass spectrometric analysis of synthesized alanine-modified peptides.

\begin{tabular}{|c|c|c|c|c|}
\hline$\#$ & Peptides & $\begin{array}{l}\text { Calculated } \\
{[\mathrm{M}+2 \mathrm{H}]^{2+}}\end{array}$ & $\begin{array}{c}\text { Observed } \\
{[\mathbf{M}+2 \mathbf{H}]^{2+}}\end{array}$ & Purity \\
\hline 1 & Fitc-Ahx-EEDFGEEAEEEA-NH ${ }_{2}$ & 942.8 & 943.6 & $>95 \%$ \\
\hline 2 & Fitc-Ahx-AEDFGEEAEEEA-NH ${ }_{2}$ & 913.8 & 914.4 & $>95 \%$ \\
\hline 3 & Fitc-Ahx-EADFGEEAEEEA-NH ${ }_{2}$ & 913.8 & 914.5 & $>95 \%$ \\
\hline 4 & Fitc-Ahx-EEAFGEEAEEEA-NH${ }_{2}$ & 920.8 & 921.4 & $>95 \%$ \\
\hline 5 & Fitc-Ahx-EEDAGEEAEEEA-NH ${ }_{2}$ & 904.8 & 905.4 & $>95 \%$ \\
\hline 6 & Fitc-Ahx-EEDFAEEAEEEA-NH ${ }_{2}$ & 949.9 & 950.6 & $>90 \%$ \\
\hline 7 & Fitc-Ahx-EEDFGAEAEEEA-NH ${ }_{2}$ & 913.8 & 914.5 & $>95 \%$ \\
\hline 8 & Fitc-Ahx-EEDFGEAAEEEA-NH 2 & 913.8 & 914.5 & $>95 \%$ \\
\hline 9 & Fitc-Ahx-EEDFGEEAAEEA-NH ${ }_{2}$ & 913.8 & 914.4 & $>90 \%$ \\
\hline 10 & Fitc-Ahx-EEDFGEEAEAEA-NH${ }_{2}$ & 913.8 & 914.4 & $>95 \%$ \\
\hline 11 & Fitc-Ahx-EEDFGEEAEEAA-NH 2 & 913.8 & 914.4 & $>90 \%$ \\
\hline
\end{tabular}

The results of the alanine scan for peptide EEDFGEEAEEEA has shown in Figure 2.

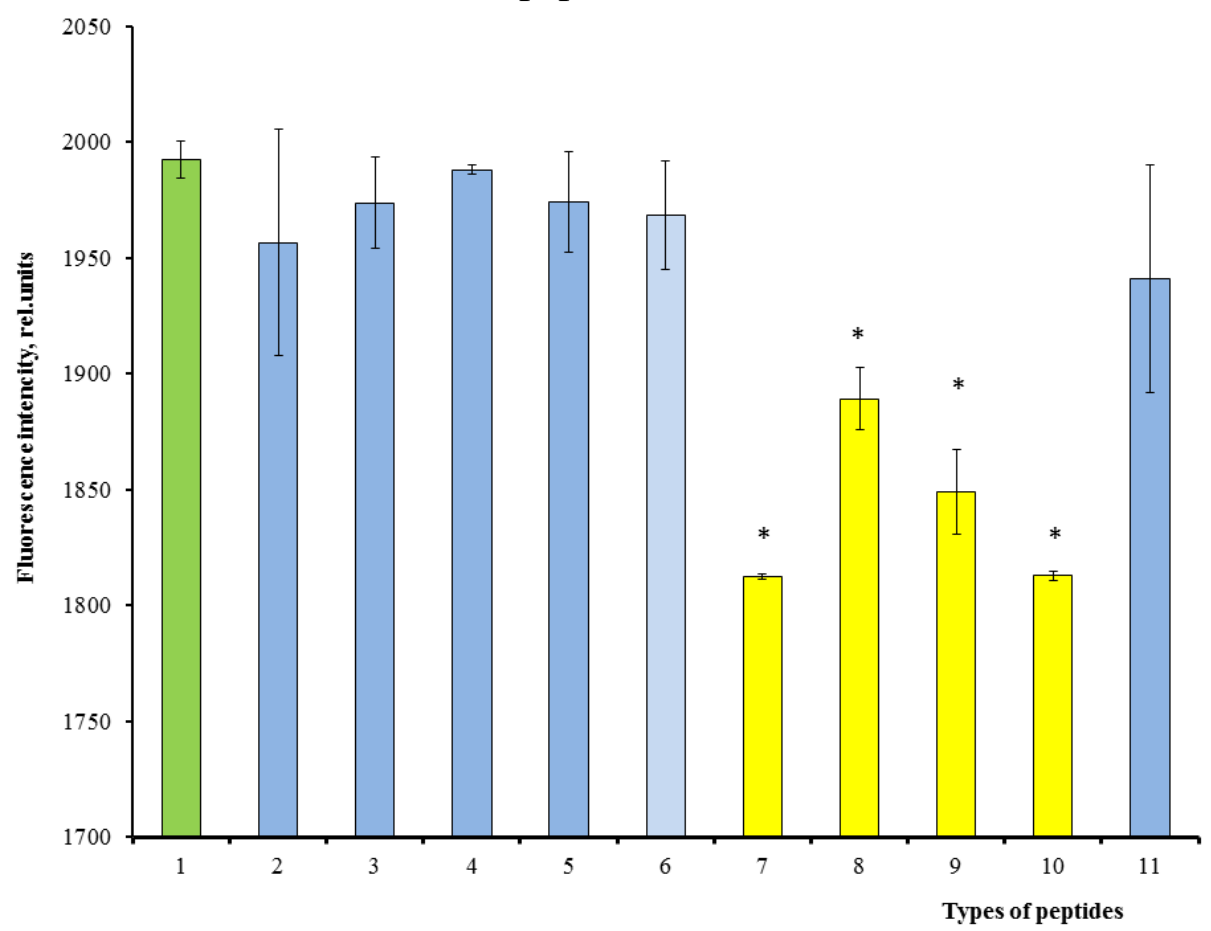

Figure 2. Alanine scan for peptide EEDFGEEAEEEA: 1- EEDFGEEAEEEA (positive control), 2-

AEDFGEEAEEEA, 3- EADFGEEAEEEA, 4- EEAFGEEAEEEA, 5- EEDAGEEAEEEA, 6-

EEDFAEEAEEEA, 7- EEDFGAEAEEEA, 8- EEDFGEAAEEEA, 9- EEDFGEEAAEEA, 10-

EEDFGEEAEAEA, 11- EEDFGEEAEEAA. The stars represent the sequences where Ala has replaced a key amino acid. $* \mathrm{p} \leq 0.05$ in relation to positive control.

The alanine scan results demonstrated that amino acids E (glutamic acid) in peptide EEDFGEEAEEEA are essential for binding with RHAMM-CT.

Then we performed an alanine scan of peptide VEGEGEEEGEEY (Figure 3). 


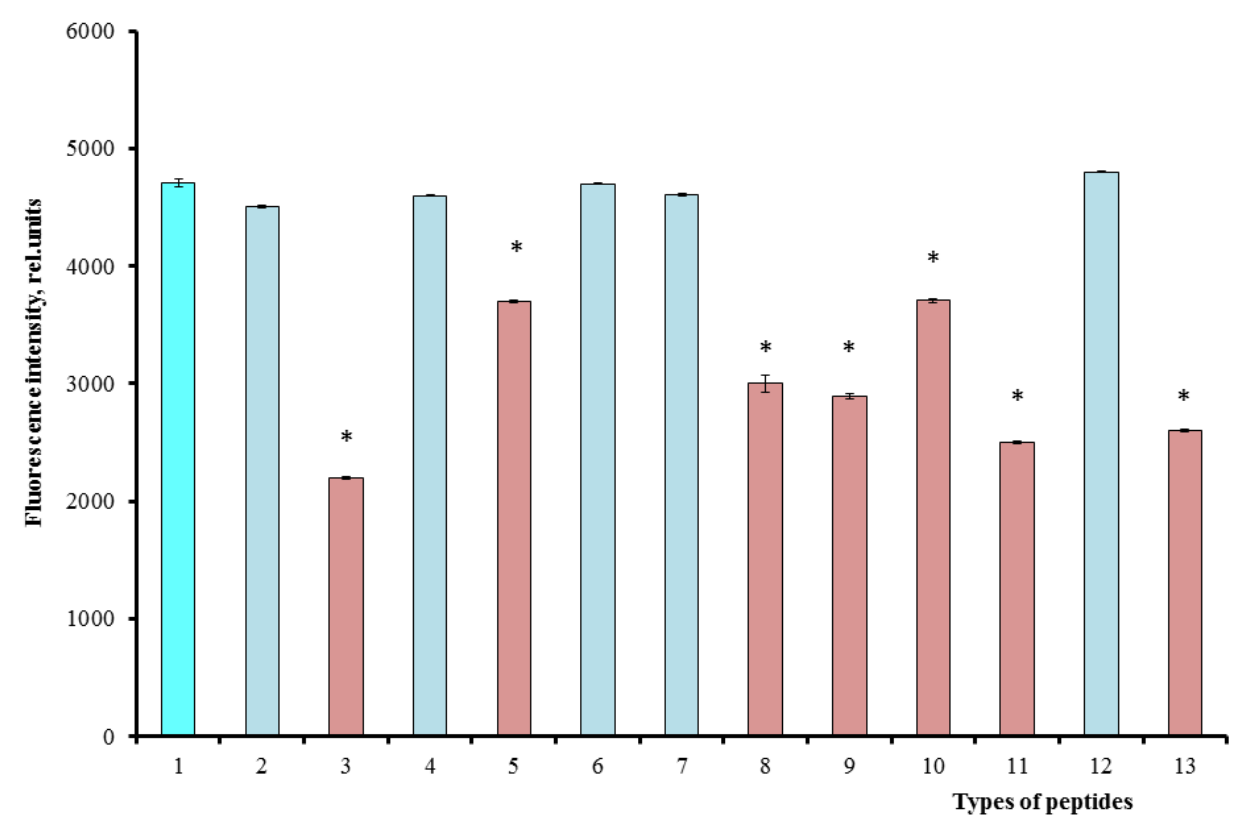

Figure 3. Alanine scan for peptide VEGEGEEEGEEY: 1- VEGEGEEEGEEY (positive control), 2AEGEGEEEGEEY , 3- VAGEGEEEGEEY, 4- VEAEGEEEGEEY, 5- VEGAGEEEGEEY, 6VEGEAEEEGEEY, 7- VEGEGAEEGEEY, 8- VEGEGEAEGEEY, 9- VEGEGEEAGEEY, 10VEGEGEEEAEEY, 11- VEGEGEEEGAEY, 12- VEGEGEEEGEAY, 13- VEGEGEEEGEEA. The stars represent the sequences where Ala has replaced a key amino acid. * $p \leq 0.05$ in relation to positive control.

The results showed that amino acids E (glutamic acid), G (glycine), Y (tyrosine) in the composition of the peptide VEGEGEEEGEEY are necessary for binding to the RHAMM-CT, since their replacement with the amino acid Ala (alanine) leads to a significant decrease in the affinity for the protein. It should be noted that these amino acids are part of the fragment EEGEE, which confirms its importance for binding at the HA center of the RHAMM.

Analysis of alanine scan of peptide FTEAESNMNDLV has shown that the amino acids $\mathrm{D}$ (aspartic acid), $\mathrm{N}$ (asparagine), $\mathrm{S}$ (serine), $\mathrm{E}$ (glutamic acid), and $\mathrm{T}$ (threonine) are key amino acids for binding with RHAMM-CT (Figure 4).

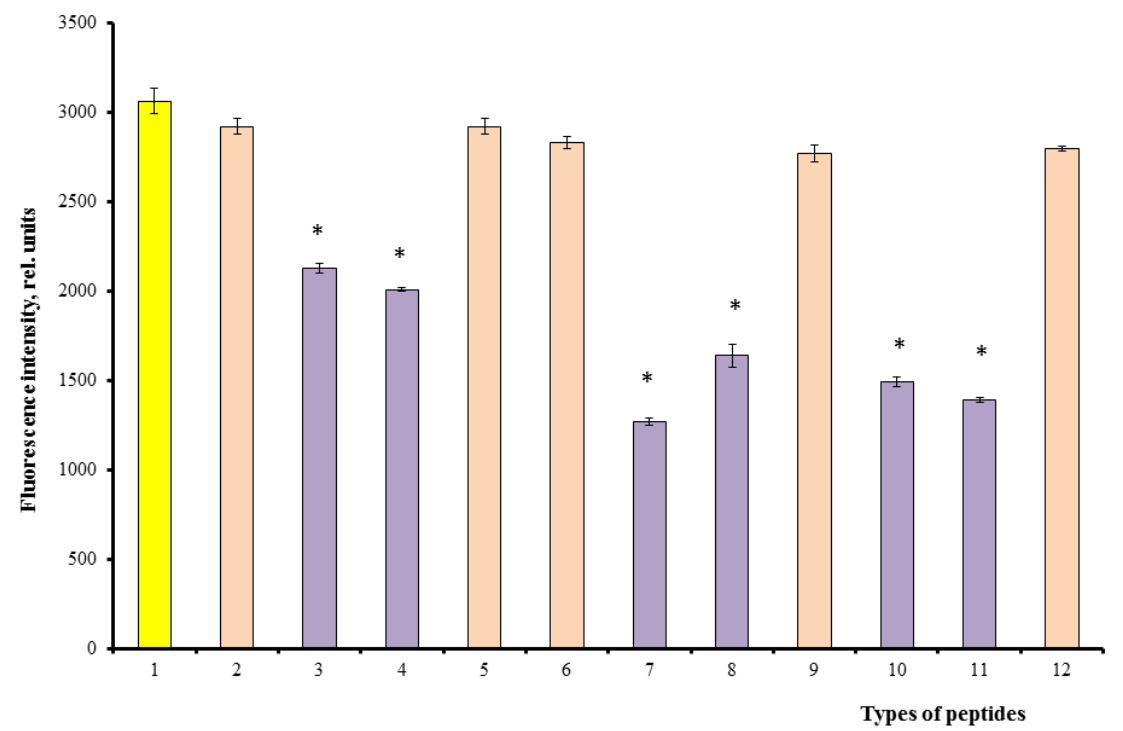

Figure 4. Alanine scan for peptide FTEAESNMNDLV: 1- FTEAESNMNDLV(positive control), 2FTEAESNMNDAV, 3- FTEAESNMNALV, 4- FTEAESNMADLV, 5- FTEAESNANDLV, 6-

FTEAESAMNDLV , 7- FTEAEANMNDLV, 8- FTEAASNMNDLV, 9- FTEAESNMNDLV, 10-

FTAAESNMNDLV, 11-FAEAESNMNDLV, 12- ATEAESNMNDLV. The stars represent the sequences where Ala has replaced a key amino acid. $* \mathrm{p} \leq 0.05$ in relation to positive control. 
Based on the alanine scan data, truncated versions of the peptides (EEDFGEEAEEEA and VEGEGEEEGEEY) were developed, containing the key amino acids shown in Figures 2, 3, and 4. These truncated peptides (DFGEEAEE and GEGEEGEE) were also used in subsequent experiments to study their RHAMM receptor binding specificity.

\subsection{Analysis of the specificity of binding of peptides to RHAMM-CT.}

The specificity of the binding of peptide-ligands to the receptor is a prerequisite for using these peptides in the treatment and diagnosis of cancer. Therefore, at the next stage of our work, we investigated the binding specificity of the obtained peptides to RHAMM-CT. All peptides (EEDFGEEAEEEA, FTEAESNMNDLV, GEGEEGEE, DFGEEAEE, RYQLHPYR) were found to bind with high affinity to the RHAMM-CT protein. However, the results showed that peptides (GEGEEGEE and RYQLHPYR) bind most efficiently to RHAMM-CT (Figure $5)$.

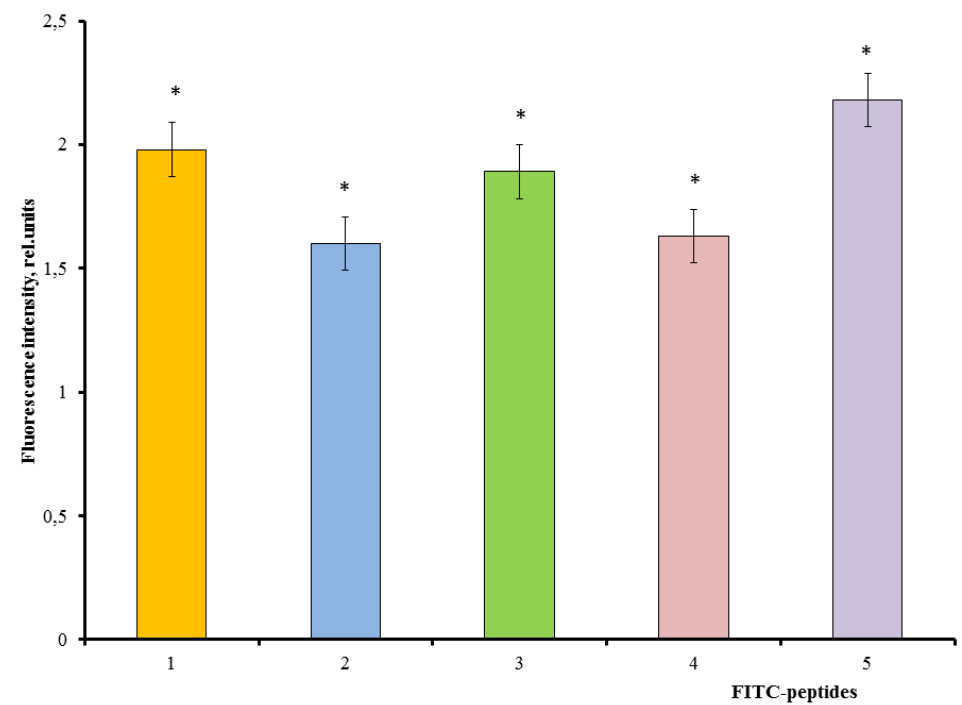

Figure 5. Assay binding FITC-labeled peptides (1- EEDFGEEAEEEA, 2- FTEAESNMNDLV, 3-GEGEEGEE, 4- DFGEEAEE, 5- RYQLHPYR) with RHAMM-CT. The study of the binding of FITC-peptides to RHAMM-

CT was carried out at a peptide concentration $10 \mu \mathrm{g} / \mathrm{ml}$. ${ }^{*} \mathrm{p} \leq 0.05$ in relation to RHAMM-CT. A negative control (no immobilized RHAMM) that showed minimal background fluorescence was subtracted for each measurement.

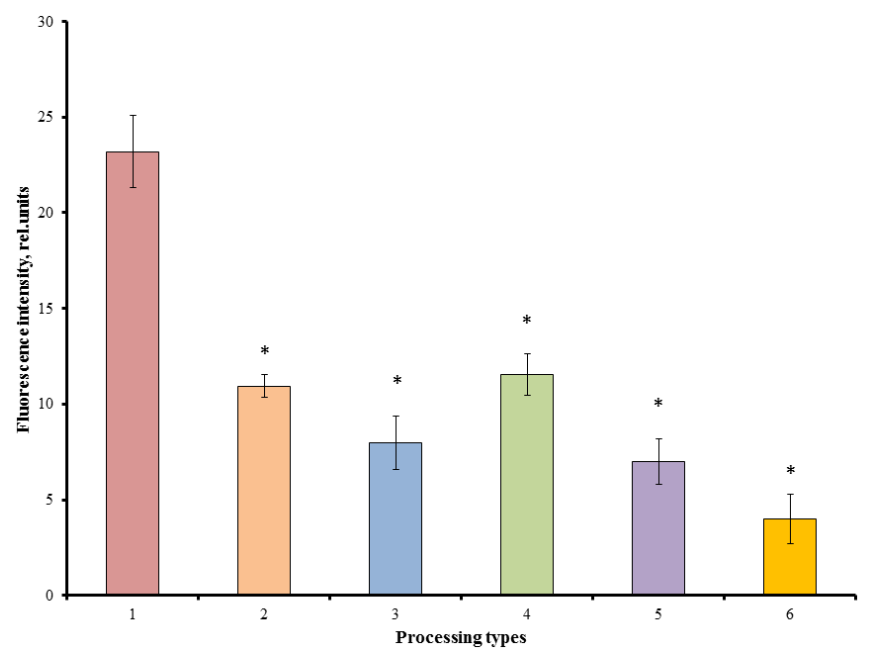

Figure 6. Competitive replacement of peptides with hyaluronic acid (labeled with Cy5.5): 1- HACy5.5, 2HACy5.5+ EEDFGEEAEEEA; 3- HACy5.5+ GEGEEGEE; 4- HACy5.5+ RYQLHPYR ; 5- HACy5.5+HA; 6-

HACy5.5+RHAMM Ab. The used concentration of peptides $(10 \mu \mathrm{g} / \mathrm{ml})$ and $\mathrm{HA}(10 \mu \mathrm{g} / \mathrm{ml}) .{ }^{*} \mathrm{p} \leq 0.05 \mathrm{in}$ relation to RHAMM-CT + HACy5.5. 
At the next stage, we continued studying the competitive binding of peptides on the RHAMM-CT HA-binding site. However, in this experiment, we used unlabeled peptides, and HA was labeled with Cy5.5 fluorescent dye (Figure 6). The results showed that HA competitively replaced peptides on the HA-binding site of RHAMM-CT. At the same time, HA most effectively competed with peptide GEGEEGEE.

\subsection{Analysis of the binding of aggrecan on the RHAMM-CT HA-binding site.}

To confirm peptide binding to the RHAMM-CT HA-binding site, we also examined peptide binding in the presence of other glycosaminoglycans such as aggrecan (Figure 7). As shown in Figure 7, aggrecan cannot displace peptides from the HA binding site. Figure 6 also shows that aggrecan does not compete with peptides for binding to the HA-binding site on RHAMM-CT. Only the addition of HA leads to the substitution of peptides at the HA-binding site of RHAMM-CT. Thus, the results showed that the obtained peptides bind specifically to the RHAMM-CT HA-binding site.

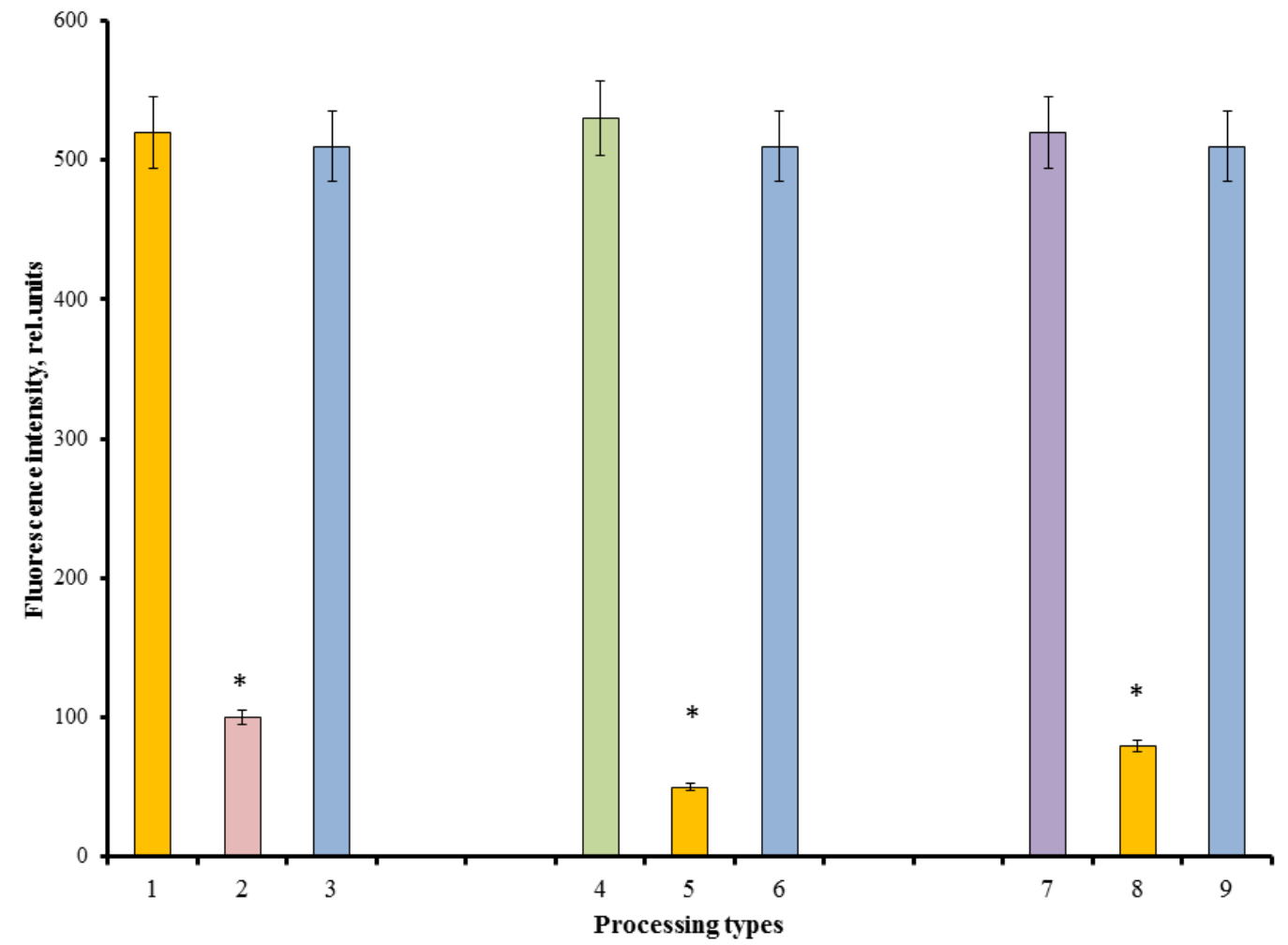

Figure7. Analysis of peptide binding on the RHAMM-CT HA-binding site in the presence of aggrecan and HA: 1- RHAMM-CT+ FITC-EEDFGEEAEEEA; 2-FITC-EEDFGEEAEEEA+HA; 3-FITC-

EEDFGEEAEEEA+aggrecan; 4- RHAMM-CT+FITC-GEGEEGEE; 5- FITC-GEGEEGEE+HA; 6-FITCGEGEEGEE+aggrecan; 7- RHAMM-CT+RYQLHPYR; 8-FITC-RYQLHPYR+HA; 9-FITCRYQLHPYR+aggrecan. * $\mathrm{p} \leq 0.05$ relative to RHAMM-CT + FITC peptides.

\subsection{Binding of FITC-peptides to the surface of prostate cancer cells.}

For the use of peptides as theranostics, it is necessary to show the specificity of the interaction of peptides with tumor cells. Therefore, at the next stage, we investigated the binding of peptides to cancer cells' surfaces.

To determine whether peptides are able to interact with RHAMM and CD44 receptors located on the surface of intact cells, we investigated the binding of FITC peptides to human tumor cells using confocal fluorescence microscopy. We used prostate cancer cells (PC3m- 
LN4) for experiments, which are known to overexpress RHAMM, CD44, and HA [53-55]. It was previously shown that these cells also bind fluorescently labeled HA [56, 57].

For this study, we selected FITC-peptide (FTEAESNMNDLV), which has previously demonstrated high binding affinity and specificity for RHAMM. Figure 8 shows confocal images demonstrating the binding of FTEAESNMNDLV peptide to cells (PC3m-LN4). Before the addition of FITC-peptide, cells were preincubated with anti-IgG, anti-CD44, or antiRHAMM antibodies. Cells that were not treated with antibodies showed intense fluorescence, indicating that the FITC-peptide binds to the cell surface (Figure 8, row 1, top).
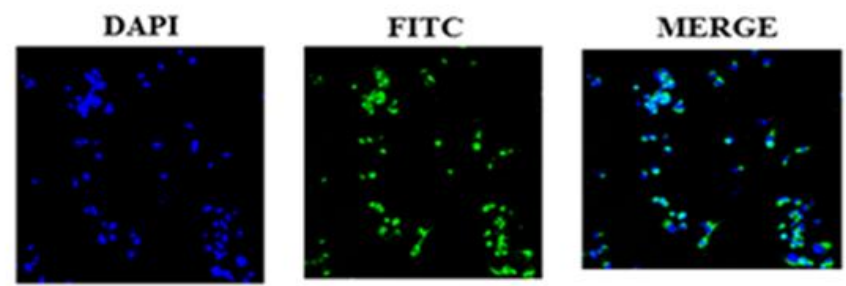

MERGE
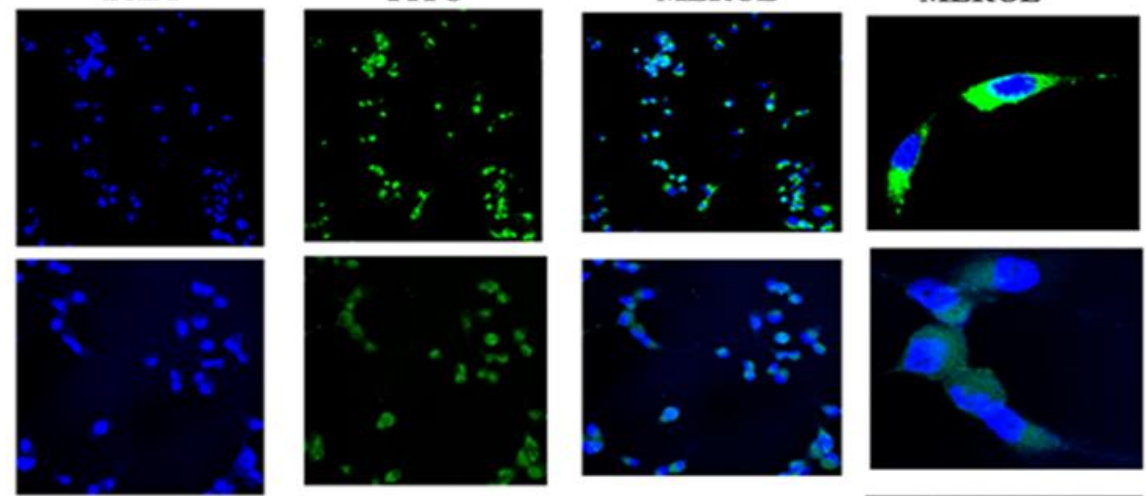

no blocking
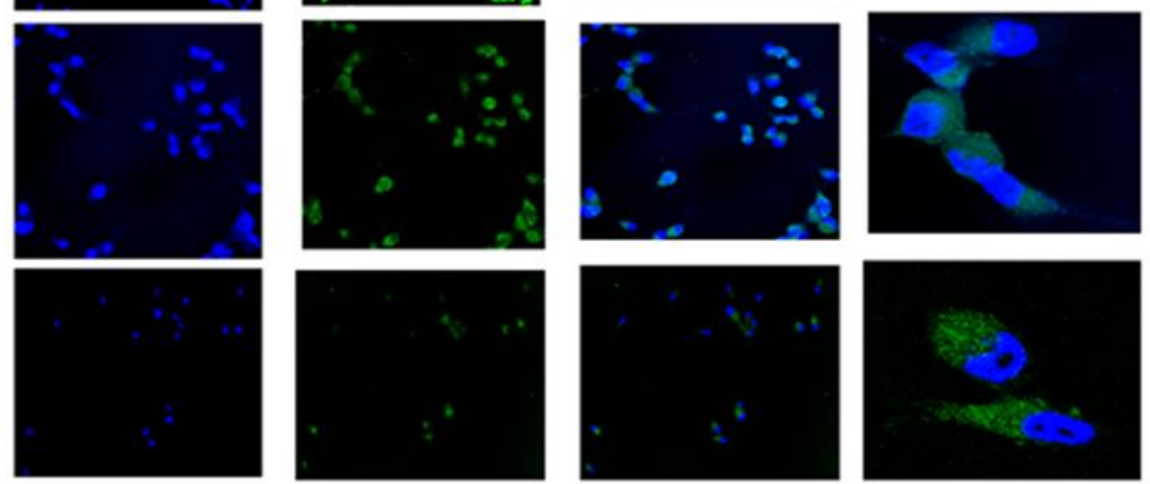

IgG Ab

blocked
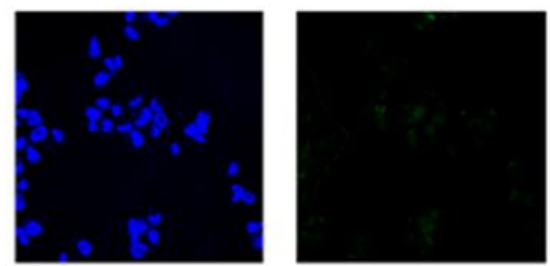

FTEAESNMNDLV

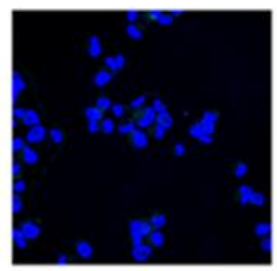

$\mathbf{x 2 0}$
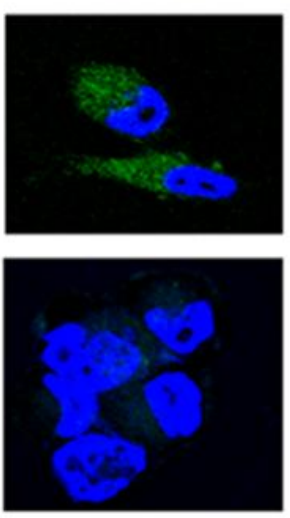

$\mathbf{x 4 0}$

Figure 8. Visualization of FITC-peptide (FTEAESNMNDLV) binding by prostate cancer cells using confocal microscopy. DAPI (blue) was used to stain the cell nuclei, and the FITC peptide was colored green (FITC). Cells were incubated with anti-IgG, anti-CD44, or anti-RHAMM antibodies before the FITC peptide addition.

Cells that were not treated with antibodies or cells treated with IgG antibodies served as positive controls.

Pre-incubation of cells with anti-IgG antibodies that interact with the FcR receptor and do not bind to RHAMM did not lead to a noticeable change in fluorescence. This indicates that blocking the FcR receptor does not affect the binding of FITC-peptide to the cell surface (Figure 8,2nd row from the top). It should be noted that cells treated with anti-CD44 antibodies (Figure 8, row 3) also showed fairly intense fluorescence. This indicates that blocking CD44 does not affect the binding of FITC-peptide to cells. As seen in Figure 8 (row 4), a significant decrease in fluorescence was observed only when cells were treated with anti-RHAMM antibodies that blocked the binding of FITC-peptide to RHAMM. Thus, the results showed that FITC-peptide binds specifically to RHAMM on the surface of breast cancer cells.

Thus, the results showed that the FITC peptide binds specifically to RHAMM on the surface of prostate cancer cells.

We also investigated the binding of peptides to ovarian cancer cells (Figure 9). The results showed that the FITC-peptide EEDFGEEAEEEA binds specifically to the RHAMM 
receptor on the surface of ovarian cancer cells since the treatment of cells with anti-RHAMM antibodies led to complete blocking of peptide binding on the cell surface. This indicates that FITC-EEDFGEEAEEEA peptide binding is RHAMM mediated.

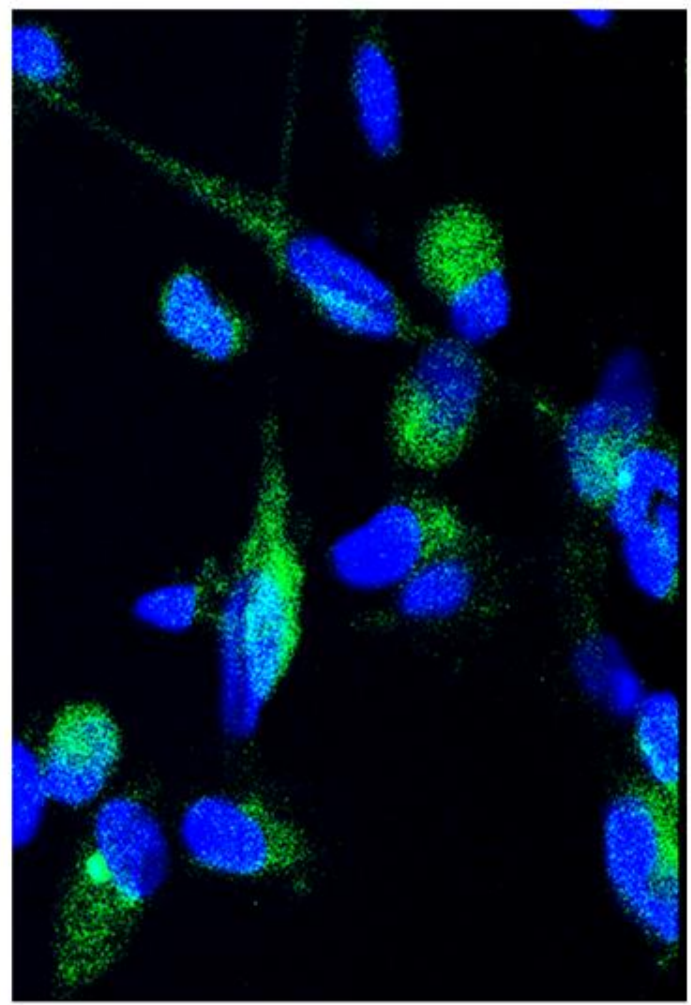

A

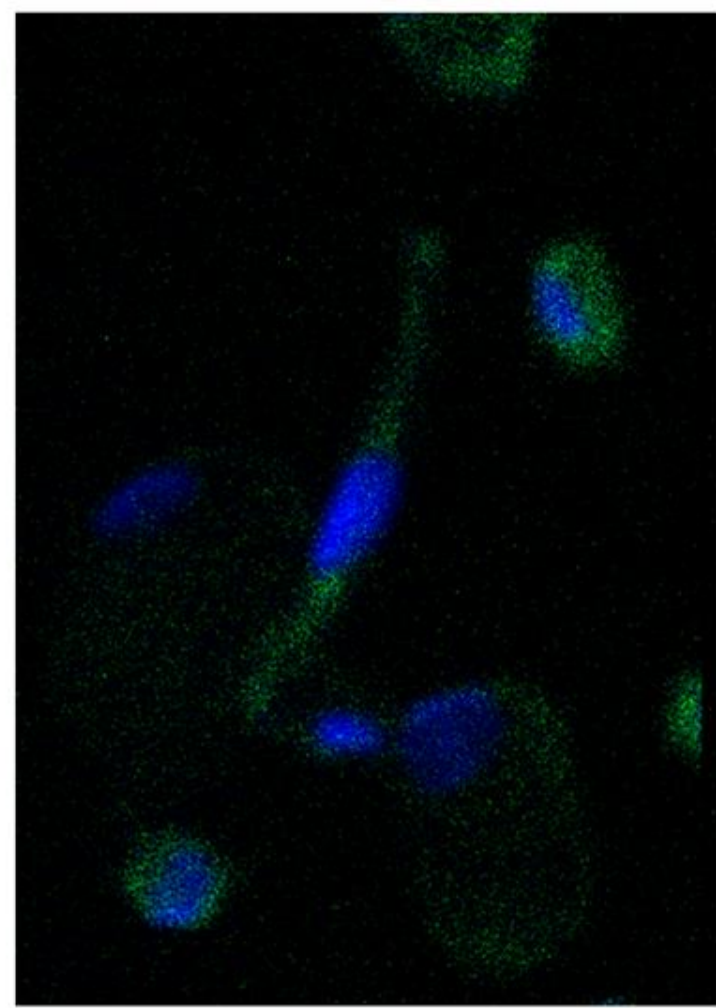

B

Figure 9. Visualization of FITC-peptide (EEDFGEEAEEEA) binding by ovarian cancer cells using confocal microscopy. DAPI (blue) was used to stain the cell nuclei, and the FITC peptide was colored green (FITC).

Cells (A, incubated with FITC-peptide) and cells after incubation with anti-RHAMM antibodies (B) prior to the addition of the FITC peptide. Cells that were not treated with antibodies served as positive controls.

Natural peptide ligands play a key role in the functioning of cells and in intercellular interactions, while they consist of a set of amino acids linked by amide bonds and usually contain less than one hundred monomers. Their low molecular weight allows them to be rapidly cleared from the blood, and their high binding specificity leads to the fact that their active concentration in the tumor is reached at nanomolar amounts. Interestingly, peptide ligands are very flexible regarding their chemical composition. It has been shown that such modifications of peptides as cyclization, the use of unnatural D-amino acids, or their combinations associated with chemical linkers can be easily developed $[58,59]$. The use of peptide ligands is usually determined by overexpression of tumor-specific receptors. The accumulation of the ligand peptide in the tumor correlates with the receptor's expression, making it possible to distinguish tumor tissue from normal tissue. Therefore, peptides conjugated to such diverse compounds as fluorescent dyes, radionuclides, or iron oxide particles are used for optical, positron emission tomography, or single-photon emission computed tomography, as well as for magnetic resonance imaging [60-62].

The ideal target ligand peptide should accumulate in the target, not in normal tissues, and when used for cancer imaging, it should be rapidly removed from circulation in order to minimize background and enhance the specific signal in relation to noise [63]. In the case of drug delivery, the accumulation of the peptide-drug conjugate in the target will increase the drug's effectiveness and reduce side effects. 
New theranostic agents have recently appeared, suitable for use in both imaging and cancer therapy [64-66]. Such naturally occurring ligand peptides are useful for peripheral imaging cancers such as breast, prostate, and melanoma. The amino acid sequences of the target peptide ligands can be determined using various methods. These methods include the development of derived sequences of natural proteins, such as, for example, endothelial vascular growth factor (VEGF) and somatostatin (SST), or the screening of peptide libraries consisting of billions of short random amino acid sequences located on viral particles [67-70]. Recently published research results suggest that the gastrin-releasing peptide receptor (GRPR) is associated with prostate cancer progression and is also overexpressed in 62-96\% of cases in primary breast tumors [71]. Naturally occurring gastrin-releasing peptide (GRP) has a high affinity for the GRPR receptor. Bombesin (YQRLGNQ-WAVGHLM) and its derivatives, which are analogs of gastrin-releasing peptide (GRP), have been studied in detail on many human tumor cell lines and xenograft tumors, including breast cancer [72-74]. These studies have shown that bombesin analogs may be useful for detecting GRPR-expressing human breast tumors by PET. Similar to the SSTR system, these peptides, consisting of the C-terminal modification of bombesin, have been successfully used to visualize prostate tumors using PET and CT in mice and humans [75-79].

Another example of peptide ligands is the natural $\alpha$-melanocyte stimulant hormone ( $\alpha$ $\mathrm{MSH}$ ) ligand, which specifically binds to the melanocortin-1 receptor (MC1R). The melanocortin-1 receptor is expressed by melanocytes in normal tissue and plays a key role in the synthesis of epidermal melanin pigments and photoprotective response through the activation of DNA repair pathways antioxidant defense. Since MC1R is highly overexpressed in primary melanomas and their metastases, imaging techniques have been developed using several peptide fragments obtained from a-melanocyte-stimulant-hormone (a-MSH) [80]. Over the past decade, MC1R ligand mimetics, radio-fluorinated metallopeptides, have been developed for PET tumor imaging. For SPECT imaging, lactam-cyclic analogs of a-MSH have been developed, which can also be used in PET, when this cyclic a-MSH is bound to DOTA residues [81]. All synthetic peptides showed better tumor uptake compared to radioactively labeled endogenous ligands in preclinical studies.

The first attempts in this direction led to the creation of the PEP-1 peptide, which was identified by the method of sequential binding of a 12-dimensional phage display to immobilized HA [82]. It was shown that PEP-1 decreased gastric stem cell proliferation and decreased $H$. pylori-induced gastric epithelial proliferation in vivo [83]. In addition, PEP-1, combined with selective activation of the adenosine A2 receptor, inhibited inflammation associated with arthritis [84, 85]. The PEP-1 peptide also reduced tumor metastasis and increased survival in mice [86]. Although PEP-1 was effective in these studies, it has not been shown to inhibit HA interactions with a specific receptor. A unique peptide RHAMM mimetic (P-15) was developed more recently using a 15-dimensional phage display approach [87]. This $\mathrm{P}-15$ peptide, which binds to HA, is unique in several respects. In contrast to PEP-1, the P-15 peptide contains the BX7B HA binding motif found in RHAMM. This peptide can bind low molecular weight HA fragments with high affinity and inhibit the binding of HA to RHAMM, but does not block the binding of HA to CD44. It was shown that peptide P-15 inhibits HAstimulated migration of RHAMM fibroblasts ${ }^{(++)}$, but does not affect migration of knockout RHAMM fibroblasts ${ }^{(--)}$. In addition, P-15 was found to reduce inflammation, angiogenesis, and fibroplasia of RHAMM $^{(++)}$cells, but not RHAMM ${ }^{(-/)}$[87]. It should be noted that the development of HA-binding peptides continues, and recently a new 42-amino acid BH-P 
peptide was developed, which contains three HA-BX7B motifs and exhibits antitumor effects, in particular, inhibits the proliferation of tumor cells and tumor growth melanoma in xenograft mice [88].

One of these methods used a phage library that contained high levels of negatively charged L- and D-amino acids, and initially, the screen included those peptides that bind to the recombinant HA-binding fragment of RHAMM [89, 90]. Positive candidates were tested for their ability to compete with HA for binding to recombinant RHAMM by ELISA. It has been shown that these peptides (for example, B2-A) bind specifically to basic amino acids in the RHAMM protein, which are known to be involved in its interaction with HA. However, the biological effects of these peptides have not been investigated.

In this work, we investigated peptides' interaction with recombinant RHAMM-CT and showed that the synthesized peptides bind with high affinity to the RHAMM-CT protein and compete with hyaluronic acid for the binding site. We have demonstrated that peptides contain key amino acids (EEXEEZ, N, G, D, Y, S) required for binding to the RHAMM receptor. We have shown that truncated versions of peptides containing key amino acids can also bind with RHAMM with high affinity and specificity.

The results of our studies showed that the binding of peptides to RHAM-CT is specific, and aggrecan is unable to compete with these peptides for the binding site. We have shown that peptides specifically interact with the RHAMM receptor on the surface of prostate cancer cells. Based on the above, we can conclude that these peptides can be used as molecular non-invasive probes for the early diagnosis of oncological diseases. However, further studies in animal models are needed. Currently, the development of peptides, HA mimetics, as therapeutic agents for treating oncological diseases continues [91-93].

\section{Conclusions}

Based on our results, we can conclude that RHAMM - target peptides can be used for the early detection, diagnosis, and progression of cancer. RHAMM target peptides are excellent candidates for molecular cancer diagnostics because they have the advantages of their small size, low molecular weight, simplicity, ease and low cost of synthesis, high selectivity, and remarkable ability to modify conjugate. In the new era of personalized / precision medicine, diagnostic and therapeutic treatments aim to use the genetic and molecular characteristics of a tumor to select a specific targeted therapy for each patient. In this aspect, RHAMM - target peptides can be considered as promising diagnostic agents.

\section{Funding}

This research was funded by the Ministry of Science and Higher Education of the Russian Federation and performed by the state task, state registration \# AAAA-A19-119071890015-6.

\section{Acknowledgments}

This research has no acknowledgment. 


\section{Conflicts of Interest}

The authors declare no conflict of interest. The funders had no role in the study's design, in the collection, analyses, or interpretation of data, in the writing of the manuscript, or in the decision to publish the results.

\section{References}

1. GBD 2017 Childhood Cancer Collaborators. The global burden of childhood and adolescent cancer in 2017: an analysis of the Global Burden of Disease Study 2017. Lancet Oncol. 2019, 20, 1211-1225. https://doi.org/10.1016/S1470-2045(19)30339-0.

2. Mitra, A.K.; Agrahari, V.; Mandal, A.; Cholkar, K.; Natarajan, C.; Shah, S.; Joseph, M.; Trinh, H.M.; Vaishya, R.; Yang, X.; Hao, Y.; Khurana, V.; Pal, D. Novel delivery approaches for cancer therapeutics. $J$ Control Release. 2015, 219, 248-268. https://doi.org/10.1016/j.jconrel.2015.09.067.

3. Bunkar, N.; Shandilya, R.; Bhargava, A.; Samarth, R.M.; Tiwari, R.; Mishra, D.K.; Srivastava, R.K.; Sharma, R.S.; Lohiya, N.K.; Mishra, P.K. Nano-engineered flavonoids for cancer protection. Front Biosci (Landmark Ed). 2019, 24, 1097-1157.

4. Bathara, M.; Date, T.; Chaudhari, D.; Ghadi, R.; Kuche, K.; Jain, S. Exploring the Promising Potential of High Permeation Vesicle-Mediated Localized Transdermal Delivery of Docetaxel in Breast Cancer To Overcome the Limitations of Systemic Chemotherapy. Mol Pharm. 2020, 17, 2473-2486. https://doi.org/10.1021/acs.molpharmaceut.0c00211

5. Yavari, B.; Mahjub, R.; Saidijam, M.; Raigani, M.; Soleimani, M. The Potential Use of Peptides in Cancer $\begin{array}{lllllll}\text { Treatment. Curr Protein } & \text { Pept } & \text { 2018, } & \text { 19, } & \text { 759-770. }\end{array}$ https://doi.org/10.2174/1389203719666180111150008.

6. Pan, J; Silva, T.C.; Gull N, Yang, Q.; Plummer, J.T.; Chen, S.; Daigo, K.; Hamakubo, T.; Gery, S.; Ding, L.W.; Jiang, Y.Y.; Hu, S.; Xu, L.Y.; Li, E.M.; Ding, Y.; Klempner, S.J.; Gayther, S.A.; Berman ,B.P.; Koeffler, H.P.; Lin, D.C. Lineage-Specific Epigenomic and Genomic Activation of Oncogene HNF4A Promotes Gastrointestinal Adenocarcinomas. Cancer Res. 2020, 80, 2722-2736. https://doi.org/10.1158/0008-5472.can-20-0390.

7. Le Joncour, V.; Laakkonen, P. Seek \& Destroy, use of targeting peptides for cancer detection and drug delivery. Bioorg Med Chem. 2018, 26, 2797-2806. https://doi.org/10.1016/j.bmc.2017.08.052.

8. McMillan, E.A.; Ryu, M.J.; Diep, C.H.; Mendiratta, S.; Clemenceau, J.R.; Vaden, R.M.; Kim, J.H.; Motoyaji, T.; Covington, K.R.; Peyton, M.; Huffman, K.; Wu, X.; Girard, L.; Sung, Y.; Chen, P.H.; Mallipeddi, P.L.; Lee, J.Y.; Hanson, J.; Voruganti, S.; Yu, Y.; Park, S.; Sudderth, J.; DeSevo, C.; Muzny, D.M.; Doddapaneni, H.; Gazdar, A.; Gibbs, R.A.; Hwang, T.H.; Heymach, J.V.; Wistuba, I.; Coombes ,K.R.; Williams, N.S.; Wheeler, D.A.; MacMillan, J.B.; Deberardinis, R.J.; Roth, M.G.; Posner, B.A.; Minna, J.D.; Kim, H.S.; White, M.A. Chemistry-First Approach for Nomination of Personalized Treatment in Lung Cancer. Cell. 2018, 173, 864-878.e29. https://doi.org/10.1016/j.cell.2018.03.028.

9. Parker, J.J.; Canoll, P.; Niswander, L.; Kleinschmidt-DeMasters, B.K.; Foshay, K.; Waziri, A. Intratumoral heterogeneity of endogenous tumor cell invasive behavior in human glioblastoma. Sci Rep. 2018, 8, 18002. https://doi.org/10.1038/s41598-018-36280-9.

10. Fisher, E.; Pavlenko, K.; Vlasov, A.; Ramenskaya, G. Peptide-Based Therapeutics for Oncology. Pharmaceut Med. 2019, 33, 9-20. https://doi.org/10.1007/s40290-018-0261-7.

11. Caon, I.; Bartolini, B.; Parnigoni, A.; Caravà, E.; Moretto, P.; Viola, M.; Karousou, E.; Vigetti, D.; Passi, A. Revisiting the hallmarks of cancer: The role of hyaluronan. Semin Cancer Biol. 2020, 62, 9-19. https://doi.org/10.1016/j.semcancer.2019.07.007.

12. Cortes, H.; Caballero-Florán, I.H.; Mendoza-Muñoz, N.; Córdova-Villanueva, E.N.; Escutia-Guadarrama, L.; Figueroa-González, G.; Reyes-Hernández, O.D.; González-Del Carmen, M.; Varela-Cardoso, M.; Magaña, J.J.; Florán, B.; Del Prado-Audelo, M.L.; Leyva-Gómez, G. Hyaluronic acid in wound dressings. Cell Mol Biol (Noisy-le-grand). 2020, 66, 191-198.

13. Vasvani, S.; Kulkarni, P.; Rawtani, D. Hyaluronic acid: A review on its biology, aspects of drug delivery, route of administrations and a special emphasis on its approved marketed products and recent clinical studies. Int J Biol Macromol. 2020, 151, 1012-1029. https://doi.org/10.1016/j.ijbiomac.2019.11.066.

14. Toole, B.P. The CD147-HYALURONAN Axis in Cancer. Anat Rec (Hoboken). 2020, 303, 1573-1583. https://doi.org/10.1002/ar.24147. 
15. Heldin, P.; Kolliopoulos, C.; Lin, C.Y.; Heldin, C.H. Involvement of hyaluronan and CD44 in cancer and viral infections. Cell Signal. 2020, 65, 109427. https://doi.org/10.1016/j.cellsig.2019.109427.

16. Spinelli, F.M.; Vitale, D.L.; Sevic, I.; Alaniz, L. Hyaluronan in the Tumor Microenvironment. Adv Exp Med Biol. 2020, 1245, 67-83. https://doi.org/10.1007/978-3-030-40146-7_3.

17. Skandalis, S.S.; Karalis, T.; Heldin, P. Intracellular hyaluronan: Importance for cellular functions. Semin Cancer Biol. 2020, 62, 20-30. https://doi.org/10.1016/j.semcancer.2019.07.002.

18. Kang, H.G.; Kim, W.J.; Kang, H.G.; Chun, K.H.; Kim, S.J. Galectin-3 Interacts with C/EBP $\beta$ and Upregulates Hyaluronan-Mediated Motility Receptor Expression in Gastric Cancer. Mol Cancer Res. 2020, 18, 403-413. https://doi.org/10.1158/1541-7786.MCR-19-0811.

19. He, F.; Zu, D.; Lan, C.; Niu, J.; Nie, X. hsa-microRNA-411-5p regulates proliferation, migration and invasion by targeting the hyaluronan mediated motility receptor in ovarian cancer. Exp Ther Med. 2020, 20, 18991906. https://doi.org/10.3892/etm.2020.8899.

20. Wang, J.; Li, X.; Wu, H.; Wang, H.; Yao, L.; Deng, Z.; Zhou, Y. EMP1 regulates cell proliferation, migration, and stemness in gliomas through PI3K-AKT signaling and CD44. J Cell Biochem. 2019, 120, 17142-17150. https://doi.org/10.1002/jcb.28974.

21. Savani, R.C.; Cao, G.; Pooler, P.M.; Zaman, A.; Zhou, Z.; DeLisser, H.M. Differential involvement of the hyaluronan (HA) receptors CD44 and receptor for HA-mediated motility in endothelial cell function and angiogenesis. J Biol Chem. 2001, 276, 36770-36778. Doi:https://doi.org/10.1074/jbc.M102273200.

22. Carvalho, A.M.; Soares da Costa, D.; Paulo, P.M.R.; Reis, R.L.; Pashkuleva, I. Co-localization and crosstalk between CD44 and RHAMM depend on hyaluronan presentation. Acta Biomater. 2021, 119, 114-124. https://doi.org/10.1016/j.actbio.2020.10.024.

23. Morla, S. Glycosaminoglycans and Glycosaminoglycan Mimetics in Cancer and Inflammation. Int J Mol Sci. 2019, 20, 1963. https://doi.org/10.3390/ijms20081963.

24. Wight ,T.N.; Kang, I.; Evanko, S.P.; Harten, I.A.; Chang, M.Y.; Pearce, O.M.T.; Allen, C.E.; Frevert, C.W. Versican-A Critical Extracellular Matrix Regulator of Immunity and Inflammation. Front Immunol. 2020, 11, 512. https://doi.org/10.3389/fimmu.2020.00512.

25. Lin, C.Y.; Kolliopoulos, C.; Huang, C.H.; Tenhunen, J.; Heldin, C.H.; Chen, Y.H.; Heldin, P. High levels of serum hyaluronan is an early predictor of dengue warning signs and perturbs vascular integrity. EBioMedicine. 2019, 48, 425-441. https://doi.org/10.1016/j.ebiom.2019.09.014.

26. Camerlingo, R.; Ferraro, G.A.; De Francesco, F.; Romano, M.; Nicoletti, G.; Di Bonito, M.; Rinaldo, M.; D'Andrea, F.; Pirozzi, G. The role of CD44+/CD24-/low biomarker for screening, diagnosis and monitoring of breast cancer. Oncol Rep. 2014, 31, 1127-1132. https://doi.org/10.3892/or.2013.2943.

27. Zhang, X.; Powell, K.; Li, L. Breast Cancer Stem Cells: Biomarkers, Identification and Isolation Methods, Regulating Mechanisms, Cellular Origin, and Beyond. Cancers (Basel). 2020, 12, 3765. https://doi.org/10.3390/cancers12123765.

28. Sarkar, A.; Chanda, A.; Regmi, S.C.; Karve, K.; Deng, L.; Jay, G.D.; Jirik, F.R.; Schmidt, T.A.; Bonni, S. Recombinant human PRG4 (rhPRG4) suppresses breast cancer cell invasion by inhibiting TGF $\beta$-HyaluronanCD44 signalling pathway. PLoS One. 2019, 14, e0219697. https://doi.org/10.1371/journal.pone.0219697.

29. Mele, V.; Sokol, L.; Kölzer, V.H.; Pfaff, D.; Muraro, M.G.; Keller, I.; Stefan, Z.; Centeno, I.; Terracciano, L.M.; Dawson, H.; Zlobec, I.; Iezzi, G.; Lugli, A. The hyaluronan-mediated motility receptor RHAMM promotes growth, invasiveness and dissemination of colorectal cancer. Oncotarget. 2017, 8, 70617-70629. https://doi.org/10.18632/oncotarget.19904.

30. Oldenburg, D.; Ru, Y.; Weinhaus, B.; Cash, S.; Theodorescu, D.; Guin, S. CD44 and RHAMM are essential for rapid growth of bladder cancer driven by loss of Glycogen Debranching Enzyme (AGL). BMC Cancer. 2016, 16, 713. https://doi.org/10.1186/s12885-016-2756-5.

31. Shalini, C.N.S.; Suman, F.R.; Jacob, J.S.; Rajendran, R.; Scott, J.X.; Latha, M.S. Prognostic significance of receptor for hyaluronan acid-mediated motility (CD168) in acute pediatric leukemias - assessment of clinical outcome, post induction, end of treatment and minimal residual disease. Hematol Transfus Cell Ther. 2018, 40, 310-316. https://doi.org/10.1016/j.htct.2018.01.008.

32. Bahrami, S.B.; Tolg, C.; Peart, T.; Symonette, C.; Veiseh, M.; Umoh, J.U.; Holdsworth, D.W.; McCarthy, J.B.; Luyt, L.G.; Bissell, M.J.; Yazdani, A.; Turley, E.A. Receptor for hyaluronan mediated motility (RHAMM/HMMR) is a novel target for promoting subcutaneous adipogenesis. IntegrBiol (Camb). 2017, 9 , 223-237. https://doi.org/10.1039/c7ib00002b. 
33. He, Z.; Mei, L.; Connell, M.; Maxwell, C.A. Hyaluronan Mediated Motility Receptor (HMMR) Encodes an Evolutionarily Conserved Homeostasis, Mitosis, and Meiosis Regulator Rather than a Hyaluronan Receptor. Cells. 2020, 9, 819. https://doi.org/10.3390/cells9040819.

34. Naor, D.; Nedvetzki, S.; Walmsley, M.; Yayon, A.; Turley, E.A.; Golan, I.; Caspi, D.; Sebban, L.E.; Zick, Y.; Garin, T.; Karussis, D.; Assayag-Asherie, N.; Raz, I.; Weiss, L.; Slavin, S.; Golan, I. CD44 involvement in autoimmune inflammations: the lesson to be learned from CD44-targeting by antibody or from knockout mice. Ann N Y Acad Sci. 2007, 1110, 233-247. https://doi.org/10.1196/annals.1423.025.

35. Wu, J.; Qu, Y.; Zhang, Y.P.; Deng, J.X.; Yu, Q.H. RHAMM induces progression of rheumatoid arthritis by enhancing the functions of fibroblast-like synoviocytes. BMC Musculoskelet Disord. 2018, $19,455$. https://doi.org/10.1186/s12891-018-2370-6.

36. Greiner, J.; Ringhoffer, M.; Taniguchi, M.; Schmitt, A.; Kirchner, D.; Krähn, G.; Heilmann, V.; Gschwend, J.; Bergmann, L.; Döhner, H.; Schmitt, M. Receptor for hyaluronan acid-mediated motility (RHAMM) is a new immunogenic leukemia-associated antigen in acute and chronic myeloid leukemia. ExpHematol. 2002, 30, 1029-1035. https://doi.org/10.1016/S0301-472X(02)00874-3.

37. Choi, S.; Wang, D.; Chen, X.; Tang, L.H.; Verma, A.; Chen, Z.; Kim, B.J.; Selesner, L.; Robzyk, K.; Zhang, G.; Pang, S.; Han, T.; Chan, C.S.; Fahey, T.J 3rd.; Elemento, O.; Du, Y.N. Function and clinical relevance of RHAMM isoforms in pancreatic tumor progression. Mol Cancer. 2019, $18,92$. https://doi.org/10.1186/s12943-019-1018-y.

38. Line, A.; Slucka, Z.; Stengrevics, A.; Silina, K.; Li, G.; Rees, R.C. Characterisation of tumour-associated antigens in colon cancer. Cancer Immunol Immunother. 2002, 51, 574-582. https://doi.org/10.1007/s00262002-0322-2.

39. Schmitt, M.; Schmitt, A.; Rojewski, M.T.; Chen, J. et al. RHAMM-R3 peptide vaccination in patients with acutemyeloid leukemia, myelodysplastic syndrome, and multiple myelomaelicits immunologic and clinical responses. Blood. 2008, 111, 1357-1365. https://doi.org/10.1182/blood-2007-07-099366.

40. Schreer, A.; Tinson, C.; Sherry, J.P.; Schirmer, K. Application of Alamar blue/5-carboxyfluorescein diacetate acetoxymethyl ester as a non-invasive cell viability assay in primary hepatocytes from rainbow trout. Anal Biochem. 2005, 344, 76-85. https://doi.org/10.1016/j.ab.2005.06.009.

41. Albericio, F. Solid-phase synthesis: a practical guide, 1 ed.; Boca Raton: CRC Press., USA, 2000; 848-849.

42. Esguerra, K.V.; Tolg, C.; Akentieva, N.; Price, M. et al. Identification, design and synthesis of tubulinderived peptides as novel hyaluronan mimetic ligands for the receptor for hyaluronan-mediated motility (RHAMM/HMMR). Integr. Biol. (Camb). 2015, 7, 1547-1560. https://doi.org/10.1039/c5ib00222b.

43. Morrison, K.L.; Weiss, G.A. Combinatorial alanine-scanning. Curr Opin Chem Biol. 2001, 5, 302-307. https://doi.org/10.1016/S1367-5931(00)00206-4.

44. Ruan, B.; Fisher, K.E.; Alexander, P.A.; Doroshko, V.; Bryan, P.N. Engineering subtilisin into a fluoridetriggered processing protease useful for one-step protein purification. Biochemistry. 2004, 43, 14539-14546. https://doi.org/10.1021/bi048177j.

45. Bradford, M.M. A rapid and sensitive method for the quantitation of microgram quantities of protein utilizing the principle of protein-dye binding. Anal. Biochem. 1976, 72, 248-254. https://doi.org/10.1016/00032697(76)90527-3.

46. Laemmli, U.K. Cleavage of structural proteins during the assembly of the head of bacteriophage T4. Nature. 1970, 227, 680-685. https://doi.org/10.1038/227680a0.

47. Towbin, H.; Staehelin, T.; Gordon, J. Electrophoretic transfer of proteins from polyacrylamide gels to nitrocellulose sheets: procedure and some applications. Proc. Nat. Acad. Sci. USA. 1979, 76, 4350-4354. https://doi.org/10.1073/pnas.76.9.4350.

48. Drummen, G. P. C. Fluorescent probes and fluorescence (microscopy) techniques-illuminating biological and biomedical research. Molecules. 2012, 17, 14067-14090. https://doi.org/10.3390/molecules171214067.

49. Nickel, W. Unconventional secretory routes: direct protein export across theplasma membrane of mammalian cells. Traffic. 2005, 6, 607-614. https://doi.org/10.1111/j.1600-0854.2005.00302.x.

50. Prudovsky, I.; Tarantini, F.; Landriscina, M.; Neivandt, D. et al. Secretion without Golgi. J. Cell. Biochem. 2008, 103, 1327-1343. https://doi.org/10.1002/jcb.21513.

51. Ye, S.; Liu, Y.; Fuller, A.M.; Katti, R.; Ciotti, G.E.; Chor, S.; Alam, M.Z.; Devalaraja, S.; Lorent, K.; Weber, K.; Haldar, M.; Pack, M.A.; Eisinger-Mathason, T.S.K. TGF $\beta$ and Hippo Pathways Cooperate to Enhance Sarcomagenesis and Metastasis through the Hyaluronan-Mediated Motility Receptor (HMMR). Mol Cancer Res. 2020. 4, 560-573. https://doi.org/10.1158/1541-7786.MCR-19-0877. 
52. Bryan, P.N. Protein engineering of subtilisin. Biochim. Biophys.Acta. 2000, 1543, $203-222$. https://doi.org/10.1016/S0167-4838(00)00235-1.

53. Heldin, P.; Basu, K.; Olofsson, B.; Porsch, H.; Kozlova, I.; Kahata, K. Deregulation of hyaluronan synthesis, degradation and binding promotes breast cancer. J. Biochem. 2013, 154, 395-408. https://doi.org/10.1093/jb/mvt085.

54. Bourguignon, L.Y.; Wong, G.; Shiina, M. Up-regulation of histone methyltransferase, DOT1L, by matrix hyaluronan promotes microRNA-10 expression leading to tumor cell invasion and chemoresistance in cancer stem cells from head and neck squamous cell carcinoma. J. Biol. Chem. 2016, 291, 10571-10585. https://doi.org/10.1074/jbc.M115.700021.

55. Montgomery, N.; Hill, A.; McFarlane, S.; Neisen, J. et al. CD44 enhances invasion of basal-like breast cancer cells by upregulating serine protease and collagen-degrading enzymatic expression and activity. Breast Cancer Res. 2012, 14, R84. https://doi.org/10.1186/bcr3199.

56. Veiseh, M.; Breadner, D.; Ma, J.; Akentieva, N. P.; Savani, R.C. et al. Imaging of ho-meostatic, neoplastic, and injured tissues by HA-base probes. Biomacromolecules. 2012, 13, 12-22. https://doi.org/10.1021/bm201143c.

57. Veiseh, M. and Turley, E. A. Hyaluronan metabolism in remodeling extracellular matrix: probes for imaging and therapy of breast cancer. Integr. Biol. (Camb). 2011, 3, 304-315. https://doi.org/10.1039/c0ib00096e.

58. Yongye, A.B.; Li, Y.; Giulianotti, M.A.; Yu, Y.; Houghten, R.A.; Martínez-Mayorga, K. Modeling of peptides containing D-amino acids: implications on cyclization. J Comput Aided Mol Des. 2009, 23, 677-89. https://doi.org/10.1007/s10822-009-9295-y.

59. Ting, D.S.J.; Beuerman, R.W.; Dua, H.S.; Lakshminarayanan, R.; Mohammed, I. Strategies in Translating the Therapeutic Potentials of Host Defense Peptides. Front Immunol. 2020, 11, 983. https://doi.org/10.3389/fimmu.2020.00983.

60. Hübner, R.; Cheng, X.; Wängler, B.; Wängler, C. Functional Hybrid Molecules for the Visualization of Cancer: PESIN-Homodimers Combined with Multimodal Molecular Imaging Probes for Positron Emission Tomography and Optical Imaging: Suited for Tracking of GRPR-Positive Malignant Tissue. Chemistry. 2020, 26, 16349-16356. https://doi.org/10.1002/chem.202002386.

61. Lahooti, A.; Shanehsazzadeh, S.; Laurent, S. Preliminary studies of 68Ga-NODA-USPION-BBN as a dualmodality contrast agent for use in positron emission tomography/magnetic resonance imaging. Nanotechnology. 2020, 31, 015102. https://doi.org/10.1088/1361-6528/ab4446.

62. Watanabe, H.; Matsushita, N.; Shimizu, Y.; Iikuni, S.; Nakamoto, Y.; Togashi, K.; Ono, M. Synthesis and characterization of a novel 18F-labeled 2,5-diarylnicotinamide derivative targeting orexin 2 receptor. Med chem comm. 2019, 10, 2126-2130. https://doi.org/10.1039/C9MD00397E.

63. Jiang, Z.; Guan, J.; Qian, J.; Zhan, C. Peptide ligand-mediated targeted drug delivery of nanomedicines. Biomater Sci. 2019, 7, 461-471. https://doi.org/10.1039/C8BM01340C.

64. Davenport, A.P.; Scully, C.C.G.; de Graaf, C.; Brown, A.J.H.; Maguire, J.J. Advances in therapeutic peptides targeting G protein-coupled receptors. Nat Rev Drug Discov. 2020, 19, 389-413. https://doi.org/10.1038/s41573-020-0062-z.

65. Pillai, M.R.A.; Nanabala, R.; Joy, A.; Sasikumar, A.; Russ Knapp, F.F. Radiolabeled enzyme inhibitors and binding agents targeting PSMA: Effective theranostic tools for imaging and therapy of prostate cancer. Nucl Med Biol. 2016, 43, 692-720. https://doi.org/10.1016/j.nucmedbio.2016.08.006.

66. Emmett, L.; Willowson, K.; Violet, J.; Shin, J.; Blanksby, A.; Lee, J. Lutetium 177 PSMA radionuclide therapy for men with prostate cancer: a review of the current literature and discussion of practical aspects of therapy. J Med Radiat Sci. 2017, 64, 52-60. https://doi.org/10.1002/jmrs.227.

67. Zhang, X.; Feng, S.; Liu, J.; Li, Q. et al. Novel small peptides derived from VEGF125-136: potential drugs for radioactive diagnosis and therapy in A549 tumor-bearing nude mice. Sci. Rep. 2017, 7, 4278. https://doi.org/10.1038/s41598-017-04513-y.

68. Watt, H.L.; Kharmate, G.; Kumar, U. Biology of somatostatin in breast cancer. Mol. Cell Endocrinol. 2008, 286, 251-261. https://doi.org/10.1016/j.mce.2008.01.006.

69. Laakkonen, P.; Vuorinen, K. Homing peptides as targeted delivery vehicles. Integr. Biol. (Camb). 2010, 2, 326-337. https://doi.org/10.1039/c0ib00013b.

70. Teesalu, T.; Sugahara, K.N.; Ruoslahti, E. Mapping of vascular ZIP codes by phage display. Methods Enzymol. 2012, 503, 35-56. https://doi.org/10.1016/B978-0-12-396962-0.00002-1.

71. Dalm, S.U.; Verzijlbergen, J.F.; De Jong, M. Review: Receptor targeted nuclear im-aging of breast cancer. Int. J. Mol. Sci. 2017, 18, E260. https://doi.org/10.3390/ijms18020260. 
72. Begum, A.A.; Moyle, P.M.; Toth, I. Investigation of bombesin peptide as a targeting ligand for the gastrin releasing peptide (GRP) receptor. Bioorg. Med. Chem. 2016, 24, 5834-5841. https://doi.org/10.1016/j.bmc.2016.09.039

73. Mansi, R.; Wang, X.; Forrer, F.; Kneifel, S.; Tamma, M.L. et al. Evaluation of a 1,4,7,10-tetra-azacyclododecane-1,4,7,10-tetra-acetic acid-conjugated bombesin-based radioantagonist for the labeling with single-photon emission computed tomography, positron emission tomography, and therapeutic radionuclides. Clin. Cancer Res. 2009, 15, 5240-5249. https://doi.org/10.1158/1078-0432.CCR-08-3145.

74. Parry, J.J.; Andrews, R.; Rogers, B.E. Micro-PET imaging of breast cancer using ra-diolabeledbombesin analogs targeting the gastrin-releasing peptide receptor. Breast Cancer Res.Treat. 2007, 101, 175-183. https://doi.org/10.1007/s10549-006-9287-8.

75. Cescato, R.; Waser, B.; Fani, M.; Reubi, J.C. Evaluation of 177Lu-DOTA-sst2 antag-onist versus 177LuDOTA-sst2 agonist binding in human cancers in vitro. J. Nucl. Med. 2011, 52, 1886-1890. https://doi.org/10.2967/jnumed.111.095778.

76. Mansi, R.; Minamimoto, R.; Mäcke, H.; Iagaru, A.H. Bombesin-targeted PET of prostate cancer. J. Nucl. Med. 2016, 57, 67S-72S. https://doi.org/10.2967/jnumed.115.170977.

77. Nanda, P.K.; Wienhoff, B.E.; Rold, T.L.; Sieckman, G.L. et al. Positron-emission to-mography (PET) imaging agents for diagnosis of human prostate cancer: agonist vs. an-tagonist ligands. In Vivo. 2012, 26, 583-592.

78. Yang, M.; Gao, H.; Zhou, Y.; Ma, Y. et al. F-labeled GRPR agonists and antagonists: a comparative study in prostate cancer imaging. Theranostics. 2011, 1, 220-229. https://doi.org/10.7150/thno/v01p0220.

79. Wieser, G.; Mansi, R.; Grosu, A.L.; Schultze-Seemann, W. et al. Positron emission tomography (PET) imaging of prostate cancer with a gastrin releasing peptide receptor antagonist--from mice to men. Theranostics. 2014, 4, 412-419. https://doi.org/10.7150/thno.7324.

80. Eberle, A.N.; Bapst, J.P.; Calame, M.; Tanner, H.; Froidevaux, S. MSH radiopeptides for targeting melanoma metastases. Adv. Exp. Med. Biol. 2010, 681, 133-142. https://doi.org/10.1007/978-1-4419-6354-3_11.

81. Zhang, C.; Zhang, Z.; Lin, K.S.; Pan, J. et al. Preclinical melanoma imaging with 68Ga-labeled $\alpha$-melanocytestimulating hormone derivatives using PET. Theranostics. 2017, 7, 805-813. https://doi.org/10.7150/thno.17117.

82. Mummert, M.E.; Mohamadzadeh, M.; Mummert, D.I.; Mizumoto, N.; Takashima, A. Development of a peptide inhibitor of hyaluronan-mediated leukocyte trafficking. J. Exp. Med. 2000, 192, 769-779. https://doi.org/10.1084/jem.192.6.769.

83. Khurana, S.S.; Riehl, T.E.; Moore, B.D.; Fassan, M. et al. The hyaluronic acid receptor CD44 coordinates normal and metaplastic gastric epithelial progenitor cell proliferation. J. Biol. Chem. 2013, 288, 1608516097. https://doi.org/10.1074/jbc.M112.445551.

84. Campo, G.M.; Avenoso, A.; D'Ascola, A.; Nastasi, G. et al. Combined treatment with hyaluronan inhibitor Pep-1 and a selective adenosine A2 receptor agonist reduces in-flammation in experimental arthritis. Innate Immun. 2013, 19, 462-478. https://doi.org/10.1177/1753425912470391.

85. Campo, G.M.; Micali, A.; Avenoso, A.; D'Ascola, A. et al. Inhibition of small HA fragment activity and stimulation of A adenosine receptor pathway limit apoptosis and reduce cartilage damage in experimental arthritis. Histochem. Cell Biol. 2015, 143, 531-543. https://doi.org/10.1007/s00418-014-1298-7.

86. Mummert, M.E.; Mummert, D.I.; Ellinger, L.; Takashima, A. Functional roles of hya-luronan in B16-F10 melanoma growth and experimental metastasis in mice. Mol. Cancer Ther. 2003, 2, 295-300.

87. Tolg, C.; Hamilton, S.R.; Zalinska, E.; Mcculloch, L.; Amin, R.; Akentieva, N.P. et al. A RHAMM mimetic peptide blocks hyaluronan signaling and reduces inflammation and fibrogenesis in excisional skin wounds. Am. J. Pathol. 2012, 181, 1250-1270. https://doi.org/10.1016/j.ajpath.2012.06.036.

88. Xu, X.M.; Chen, Y.; Chen, J.; Yang, S.; Gao, F.; Underhill, C.B.; Creswell, K.; Zhang, L. A peptide with three hyaluronan binding motifs inhibits tumor growth and induces apoptosis. Cancer Res. 2003, 63, 56855690.

89. Toole, B.P.; Hascall, V.C. Hyaluronan and tumor growth. Am. J. Pathol. 2002, 161, 745-747. https://doi.org/10.1016/S0002-9440(10)64232-0.

90. Ziebell, M.R.; Prestwich, G.D. Interactions of peptide mimics of hyaluronic acid with the receptor for hyaluronan mediated motility (RHAMM). J. Comput. Aided Mol. Des. 2004, 18, 597-614. https://doi.org/10.1007/s10822-004-5433-8.

91. Hauser-Kawaguchi, A.; Luyt, L.G.; Turley, E. Design of peptide mimetics to block pro-inflammatory functions of HA fragments. Matrix Biol. 2019, 78-79, 346-356. https://doi.org/10.1016/j.matbio.2018.01.021. 
92. Hauser-Kawaguchi, A.; Tolg, C.; Peart, T.; Milne, M.; Turley, E.A.; Luyt, L.G. A truncated RHAMM protein for discovering novel therapeutic peptides. Bioorg. Med. Chem. 2018, 26, 5194-5203. https://doi.org/10.1016/j.bmc.2018.09.018.

93. Bourguignon, L.Y.W. Matrix hyaluronan-CD44 interaction activates microRNA and LncRNA signaling associated with chemoresistance, invasion, and tumor progression. Front. Oncol. 2019, 9, 492. https://doi.org/10.3389/fonc.2019.00492. 